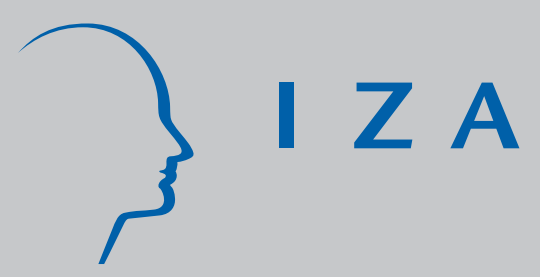

IZA DP No. 4137

Performance Pay and Within-Firm Wage Inequality

Erling Barth

Bernt Bratsberg

Torbjørn Hægeland

Oddbjørn Raaum

April 2009 


\title{
Performance Pay and Within-Firm Wage Inequality
}

\author{
Erling Barth \\ Institute for Social Research, Oslo \\ and IZA \\ Bernt Bratsberg \\ Ragnar Frisch Centre for Economic Research \\ Torbjørn Hægeland \\ Statistics Norway and \\ Ragnar Frisch Centre for Economic Research \\ Oddbjørn Raaum \\ Ragnar Frisch Centre for Economic Research
}
Discussion Paper No. 4137
April 2009

\author{
IZA \\ P.O. Box 7240 \\ 53072 Bonn \\ Germany \\ Phone: +49-228-3894-0 \\ Fax: +49-228-3894-180 \\ E-mail: iza@iza.org
}

\begin{abstract}
Any opinions expressed here are those of the author(s) and not those of IZA. Research published in this series may include views on policy, but the institute itself takes no institutional policy positions.

The Institute for the Study of Labor (IZA) in Bonn is a local and virtual international research center and a place of communication between science, politics and business. IZA is an independent nonprofit organization supported by Deutsche Post Foundation. The center is associated with the University of Bonn and offers a stimulating research environment through its international network, workshops and conferences, data service, project support, research visits and doctoral program. IZA engages in (i) original and internationally competitive research in all fields of labor economics, (ii) development of policy concepts, and (iii) dissemination of research results and concepts to the interested public.
\end{abstract}

IZA Discussion Papers often represent preliminary work and are circulated to encourage discussion. Citation of such a paper should account for its provisional character. A revised version may be available directly from the author. 


\section{ABSTRACT \\ Performance Pay and Within-Firm Wage Inequality ${ }^{*}$}

This paper examines the impact of performance-related pay on wage differentials within firms. Our theoretical framework predicts that, compared to a fixed pay system, pay schemes based on individual output increase within-firm wage inequality, while group-based bonuses have minor effects on wage dispersion. Theory also predicts an interaction between performance-related pay and union bargaining, where union power reduces the impact of performance pay on wage dispersion. The empirical contribution utilizes two recent Norwegian employer surveys, linked to a full set of individual employee pay records. A longitudinal sub-sample allows for identification based on fixed establishment effects. Introduction of performance-related pay is shown to raise residual wage inequality in nonunion firms, but not in firms with high union density. Our findings suggest that even though performance-related pay appears to be on the rise, the overall impact on wage dispersion is likely to be small, particularly in European countries with strong unions.

JEL Classification: J31, J33

Keywords: $\quad$ performance related pay, wage inequality, union bargaining

Corresponding author:

Erling Barth

Institute for Social Research

$\mathrm{Pb} .3233$ Elisenberg

0208 Oslo

Norway

E-mail: eba@socialresearch.no

\footnotetext{
*We are grateful to Carlo Dell'Aringa, Alex Bryson, Donna Ginther and Espen Moen for comments on earlier versions of this paper. We also thank participants at the 2006 workshop on the Use and Analysis of Employer Employee Data in Oslo, and the 2006 Lower Conference in Esbjerg, as well as seminar participants at the Catholic University of Milan and University of Oslo, for useful comments. This work has received financial support from the Norwegian Research Council (grants \# 156035/S20 and 173591/S20), the Norwegian Ministry of Labour and Social Inclusion (Frisch project \#1391), the EDWIN project of the European Commission IHP project (grant \#HPSE-CT-2002-00108), and is part of the research at the ESOP Centre at the Department of Economics, University of Oslo. ESOP is supported by the Norwegian Research Council.
} 


\section{Introduction}

Performance-related pay and individualized wage setting appears to be on the rise, even in economies with strong unions. Linking pay to firm performance has long been a predominant method of rewarding executive managers (Jensen and Meckling, 1976; Holmström and Milgrom, 1987). But individualized pay and performance-related pay seem to be spreading to lower ranks of employees within organizations, and throughout the labor market as well, see Lemieux et al. (2009) for recent evidence from the US and Kersley et al. (2006) for the UK. In Europe, where union-negotiated, fixed wages have been predominant, this development represents an important break with traditional forms of remuneration. An important question is whether such developments have consequences for wage inequality. This paper develops a theoretical framework for analyzing the effects of performance-related pay on within-firm wage dispersion, and confronts theory with evidence from a rich employer-employee data set.

Performance pay may affect wage dispersion differently depending on the institutional environment in which it is implemented. In particular, the presence of unions and collective wage bargaining may alter the conditions for and the design of performance-related pay schemes. Understanding the interplay between pay systems and union bargaining is thus crucial in order to understand the development of pay setting regimes, especially in European labor markets where unions are prevalent, as well as to understand differences in levels and changes in within-group wage dispersion across economies.

Three features of unions are important in the context of performance pay. First, unions appropriate rent, see, e.g., Blanchflower and Bryson (2003) on the union-nonunion wage gaps in the UK and the US. The bargaining power of unions needs to be incorporated in models of wage formation even if contracts include performance based components. Under bargaining, the wage policy of the firm is typically not constrained by outside options (i.e., a participation constraint), but will be limited by union power. Second, unions tend to compress wages. Wage dispersion is typically lower in unionized environments, see, e.g., Freeman and Medoff (1984) and Card et al. (2004). ${ }^{1}$ Since performance pay may induce worker heterogeneity in effort and productivity, and

\footnotetext{
${ }^{1}$ A large literature has paired variation in unionism and wage inequality across time and space. DiNardo et al. (1996), for example, conclude that declining unionism contributed to a considerable portion of the increase in US wage inequality during the 1980s. Kahn (2000) argues that collective coverage explains a large part of the observed differences in wage dispersion across countries.
} 
therefore pay, a theoretical framework must specify the wage compressing motives of the union. We consider a utilitarian union that represents the interests of risk-averse employees. Risk aversion implies that more weight is put on low pay than on high pay, providing collective preferences that favor pay equality. Third, unions alter information flows. Freeman and Medoff (1984) argue that unions provide workers with a "collective voice" that improves the information flow within the firm. In particular, unions may voice grievances or preferences about workplace conditions that individual workers are reluctant to put forward. In the agency literature, the important information problem is lack of observability (or at least verifiability) of effort. We argue that a union may operate as a monitoring device. ${ }^{2}$ It is easier and less costly for co-workers than for management to observe each others' daily work. A higher level of trust among workers facilitates information sharing across employees. Consequently, the union may be able to enforce a given job standard, without substantial monitoring costs. The problem for the firm, then, is how to provide the union incentives to uphold a certain job standard. A group bonus may serve this purpose. The advantage of a bonus based on collective, rather than individual, outcomes is that risk is shared among workers.

The theoretical literature on performance pay typically considers employer strategic behavior in the context of incomplete information about worker characteristics and/or behavior. Our theoretical analysis of performance pay includes a regime with union bargaining in order to derive hypotheses about the interaction between the two forms of wage setting. We analyze both individual and group-based performance pay schemes. It turns out that in the union bargaining case, the trade-off between individual and group-based pay schemes depends on the relative importance of risk sharing within the group versus the efficiency loss associated with enforcing a common job standard.

Our theoretical model predicts that (i) performance pay will raise within-firm wage dispersion, but (ii) the impact of introducing performance pay is smaller in the union case than in the nonunion case, (iii) within-firm wage dispersion under group-based performance pay systems (where an effort standard is monitored by the union) is likely to be similar to that found under

\footnotetext{
${ }^{2}$ See Pencavel (1977) for an early discussion of such a mechanism. According to Metcalf (2003), the Donovan Commission (1968) study of UK shop stewards emphasized the shop stewards' role in communication, information, and discipline of workers. See also Vroman (1990), who uses a similar mechanism to explain the cyclical behavior of the union-nonunion wage differential in an efficiency wage model.
} 
fixed-pay collective bargaining, and that (iv) group-based performance pay systems are likely to be more prevalent in a union setting.

The empirical analysis identifies the effect of introducing performance-related pay on the conditional within-establishment wage distribution, using a representative panel of two employer surveys from Norway, matched with the full set of individual employee records. The data allow us to use a comprehensive set of controls, both at the worker and at the firm level. Moreover, we obtain identification using establishment fixed effects. Controlling for establishment effects allows us to account for firm-specific heterogeneity. A sample restricted to stayers further enables us to sweep out the effect of worker sorting across firms.

\section{Empirical studies of performance pay}

The empirical literature analyzing the effects of performance-related pay focuses primarily on productivity and wage levels, and few studies explicitly address implications for inequality. Early studies of incentive schemes provide evidence of wage premiums for piece-rate workers (see, e.g., Pencavel, 1977). Seiler (1984) uses establishment data for two (four-digit) US industries and finds that incentive workers receive higher earnings than other workers, in part to compensate for their higher risk and partially due to their greater effort. Brown (1992) extends the variety of wage contracts studied to include merit pay in addition to standard and piece rate pay schemes. His empirical analysis of ten US industries focuses on wage levels and not dispersion within firms. Contradicting his own theory, Brown uncovers evidence that meritbased workers are paid less than standard time rate employees, who in turn earn less than piece rate workers. Using individual level data drawn from the NLSY, Ewing (1996) finds that workers with performance pay receive a conditional average wage premium of about five percent (without controlling for unobserved heterogeneity). In a comprehensive study of the interplay between job characteristics and different forms of compensation, MacLeod and Parent (1999) conclude that both piece rate and commission contracts are associated with greater worker autonomy (a pattern that is consistent with the theoretical model discussed in the present paper).

Longitudinal studies such as Parent (1999), Booth and Frank (1999), and Pekkarinen and Riddell (2008) account for non-random selection of workers into performance pay contracts, basically by estimating fixed effect models. These studies all conclude that workers on individual performance pay contracts are paid higher wages than other workers, but that the effect interacts 
negatively with tenure (Parent, 1999) and job complexity (Pekkarinen and Riddell, 2008). Key individual firm studies include Lazear's (2000) study of the Safelite Glass Corporation, where the introduction of piece rates raised productivity substantially, partly because of the incentive effect. In the Shearer (2004) study of British Columbia tree planting firms, productivity gains were close to 20 percent. In their real-life experimental study of fruit pickers in a UK company, Bandiera et al. (2005) find that productivity was 50 percent higher under piece rates than under relative incentives.

Turning to performance pay and wage dispersion, the Seiler study, based on US establishment data, finds that earnings of incentive workers are more dispersed than earnings of other workers, both within firms and occupations. In the Lazear Safelite study, the variance of output across individuals rose when the firm shifted to piece rates. Among large scale analyses based on representative data sets, Belfield and Marsden (2003) uncover a positive association between performance-related pay and a crude measure of pay inequality among UK establishments. Parent (1999) shows that unobserved worker productivity explains most of the wage variation among performance pay workers in his US sample, while, in contrast, wage dispersion among other workers predominantly is driven by other factors. Using data drawn from the PSID and the NLSY, Lemieux et al. (2009) explicitly address inequality implications when they study the effect of performance pay on recent developments of the US wage structure. The authors conclude that the "growing incidence of performance pay accounts for 25 percent of the growth in [the US] male wage inequality between the late 1970s and early 1990s."

Few studies link unionism and performance pay, and the empirical evidence from these studies appears inconclusive. Brown (1990) finds that unionized establishments make greater use of standard-rate pay than nonunion establishments, but no significant effect of unionism on use of incentive pay. Heywood et al. (1997) document less use of performance-related pay in unionized establishments, while Booth and Frank (1999) and Booth and Francesconi (2000) uncover positive associations between union status and performance pay. On wage effects, Booth and Frank conclude that performance pay is associated with higher wages and more so for nonunion workers. Their BHPS-based longitudinal sample is too small, however, to provide reliable fixed-effects estimates by union status and the survey does not distinguish between individual and group-based pay schemes. To our knowledge, no study has explicitly addressed how the presence of bargaining influence the wage dispersion effects of performance pay. 


\section{A Theoretical Model}

Our point of departure is a simple principal agent model in which performance pay is introduced in order to induce effort from the worker. ${ }^{3}$ To analyze the effects of payment schemes on wage dispersion within firms, we introduce individual heterogeneity along two dimensions. Workers differ in observable productivity $\left(\alpha_{i}\right)$ as well as 'efficiency,' defined as the ability to transform effort $\left(z_{i}\right)$ into valuable output. Heterogeneous efficiency across workers is represented by $p_{i}$ which is an observable exogenously given parameter. The total value of a single worker's output is given by

(1) $Y_{i}=\alpha_{i}+p_{i}\left(z_{i}+\varepsilon_{i}\right), \quad \varepsilon_{i} \sim N\left(0, \sigma^{2}\right)$

where luck is measured by $\varepsilon_{i}$. The agency problem arises because it is hard to distinguish whether changes in output is caused by effort $\left(z_{i}\right)$ or luck $\left(\varepsilon_{i}\right)$. Unless costly monitoring devices are implemented, the employer only observes the sum of the effort-induced contribution and the random component. Effort $z_{i}$ is chosen optimally by the worker, subject to constraints that vary across pay schemes. We assume that $p_{i}$ has a log-normal distribution across workers;

$$
\ln p_{i} \sim N\left(-\gamma^{2} / 2, \gamma^{2}\right)
$$

where the normalization ensures that the expectation of the efficiency distribution across workers is unity;

$$
E\left(p_{i}\right)=1 \quad, V\left(p_{i}\right)=\exp \left(\gamma^{2}\right)-1 .
$$

The parameter $\gamma$ captures the heterogeneity of effort efficiency across workers, and an increase in $\gamma$ represents a mean-preserving spread of the efficiency distribution. We assume that employers observe productivity $\left(\alpha_{i}\right)$ and effort efficiency $\left(p_{i}\right)$ of each worker. Thus, wage contracts can be specified conditional on these characteristics. ${ }^{4}$

The employer may observe individual effort (or equivalently, $\varepsilon_{i}$ ) by means of a costly monitoring scheme implemented through a set of rules or conditions related to the job, rather

\footnotetext{
${ }^{3}$ See Holmström and Milgrom (1987). For textbook expositions, see, e.g., Lazear (1995) and Cahuc and Zylberberg (2005).

${ }^{4}$ As we show below, this means that the firm will set the wage so that the expected utility of workers equals their reservation level, thus implying that sorting of workers across firms and pay regimes may be considered to be random. This is in contrast to a model where pay for performance is introduced in order to attract more efficient workers (see, e.g., Lazear, 1995).
} 
than to particular individuals, taking the form of a (common) standard for all workers. With monitoring, the employer is able to enforce a common effort standard $(\bar{z})$ at a cost, $M$, where ${ }^{5}$ (4) $\quad M(\bar{z})=n \lambda \bar{z}$.

The parameter $n$ denotes the number of workers at the firm and $\lambda \geq 0$ is the marginal cost of measuring (in a verifiable way) effort. A positive $\lambda$ implies that it is more costly to monitor and verify workers' effort the higher is the level of effort. For example, it may be inexpensive to verify a worker's presence at work, but costly to verify the work intensity or concentration provided during this presence.

We consider the following simple linear pay scheme:

$$
W_{i}=\omega_{i}+b_{i} p_{i}\left(z_{i}+\varepsilon_{i}\right)
$$

where $\omega_{i}$ is a fixed component of the wage, and $b_{i}$ is the piece rate (or the worker's share of the effort-induced productivity). We allow the share to vary across workers, but we will show shortly that it is optimal to have a common value for all. A fixed pay regime $(F P)$ means that $b_{i}=$ 0 , while a performance pay regime $(P P)$ is characterized by $0<b_{i} \leq 1$.

Workers are risk averse and care about both wages and effort. Individual utility is given by

$$
U_{i}=-\exp \left[-a\left(W_{i}-C\left(z_{i}\right)\right)\right]
$$

where $a>0$ is a measure of risk aversion, and $C\left(z_{i}\right)$ is the cost of providing effort, $z_{i}$. We assume convex effort costs, given by:

$$
C\left(z_{i}\right)=\frac{1}{2} c z_{i}^{2} .
$$

$c$ is a positive shift parameter in the marginal effort cost function. With performance pay, worker (ex post) utility depends on the normally distributed random component $\varepsilon_{i}$. Substituting in from equations (5) and (7), and taking the expectation of equation (6), the expected utility of an individual worker is given by

$$
\begin{aligned}
& E U_{i}=-\exp \left(-a \Psi_{i}\right) \\
& \Psi_{i}=\omega_{i}+b_{i} z_{i}-\frac{1}{2} c z_{i}^{2}-\frac{1}{2} b_{i}^{2} p_{i}^{2} a \sigma^{2} .
\end{aligned}
$$

\footnotetext{
${ }^{5}$ In principle, it may be optimal for the firm to let the effort requirement vary across workers. At the same time, monitoring technology will make it less costly to impose a common standard. We assume that the latter effect dominates.
} 
Note that $E\left[\exp \left(-a b_{i} p_{i} \varepsilon_{i}\right)\right]=\exp \left[-(1 / 2) a p_{i}^{2} b_{i}^{2} \sigma^{2}\right]$ since $\varepsilon_{i} \sim N\left(0, \sigma^{2}\right)$.

\subsection{The Nonunion Firm}

The firm maximizes expected profits $(\pi)$, given by

$$
\pi=\sum_{i=1}^{n}\left[\alpha_{i}+\left(1-b_{i}\right) p_{i}\left(z_{i}+\varepsilon_{i}\right)-\omega_{i}\right]-\lambda n \bar{z},
$$

and chooses the optimal remuneration scheme subject to a set of participation and incentive constraints. Participation requires that the expected utility of each worker matches her outside option, $X_{i}$, (i.e., $E U_{i}=-\exp \left(-a \Psi_{i}\right) \geq-\exp \left(-a X_{i}\right)$ ). In general, the outside option is increasing in the observed productivity component, $\alpha_{\mathrm{i}}$, but we do not need to specify the relationship in detail in order to proceed.

The incentive constraints differ by pay regime. When the firm does not monitor effort (and $\operatorname{sets} \bar{z}=0$ ), the worker chooses effort to maximize expected utility, subject to the remuneration scheme. The optimal effort for the worker is given by $z_{i}=b_{i} p_{i} / c$. (We return to the determination of $b_{i}$ below.) If the firm chooses a common effort standard $(\bar{z}>0)$ that is verified by the monitoring technology, a fixed pay contract will be preferred. ${ }^{6}$

\section{Case 1: Fixed Pay (FP)}

In the fixed pay regime $\left(b_{i}=0\right)$, effort is determined by a common standard and the firm chooses a set of individual-specific fixed wages, $\omega_{i}$, to match the workers' outside options. An optimal effort standard $(\bar{z})$ maximizes profits subject to the participation (outside option) constraint. The optimal effort standard follows from equalizing marginal gains and marginal costs, which in the Appendix is shown to yield

$$
\bar{z}=\frac{(1-\lambda)}{c} .
$$

The marginal revenue per worker, net of monitoring costs, from raising the job standard is equal to $(1-\lambda)$. When the firm raises the job standard, it must also increase wages to compensate for higher effort. The average marginal cost per worker of increasing effort is simply given by $c \bar{z}$.

\footnotetext{
${ }^{6}$ This follows from the fact that a positive $b_{i}$ requires some wage compensation for risk, while it does not contribute to effort, which in this case is determined by the common job standard.
} 
Note that the optimal effort standard is decreasing in both monitoring costs and average effort costs. The fixed pay is given by

$$
\text { (11) } W_{i}=X_{i}+\frac{1}{2 c}(1-\lambda)^{2} \text {. }
$$

With fixed pay, workers receive a wage that matches their outside option plus a compensation for effort which is common to all workers. Thus, the within-firm wage dispersion (as measured by the variance of $W$ ) reflects worker heterogeneity in outside options only:

$$
\operatorname{Var}(W)=\operatorname{Var}(X) \text {. }
$$

Under fixed pay there is no impact of the luck component, simply because the firm bears all of the risk.

\section{Case 2: Performance Pay (PP)}

Instead of monitoring workers, the firm may choose $b_{i}$ and $\omega_{i}$ to maximize profits, subject to the incentive and participation constraints. The optimal piece rate, as shown in the Appendix, is given by

$$
b_{i}=b=\frac{1}{1+a c \sigma^{2}} .
$$

In line with the literature, the optimal piece rate is decreasing in risk aversion and the marginal cost of effort. It may seem surprising that $b$ is independent of the efficiency of workers $\left(p_{i}\right)$. It is well known, however, that the optimal power of the incentive $(b)$ arises from a trade-off between risk compensation and the value of the effort induced. In our model the efficiency of a worker $\left(p_{i}\right)$ increases both the necessary compensation for risk and the value of increased effort proportionally, and thus it does not affect the trade-off between the two. The individual wage is given by

$$
W_{i}=X_{i}+\frac{1}{2 c} b p_{i}^{2}+b p_{i} \varepsilon_{i}
$$

where the deterministic part includes the outside option and a term which represents the share of the effort-induced output received by the worker, minus effort costs plus the compensation for risk since $\frac{\left(b p_{i}\right)^{2}}{c}-\frac{c}{2}\left(\frac{b p_{i}}{c}\right)^{2}+\frac{1}{2} b^{2} p_{i}^{2} a \sigma^{2}=\frac{1}{2 c} b p_{i}^{2}$. 
In contrast to the fixed pay regime, there is i) a risk to be compensated and ii) the worker receives a fraction of the luck component. Note also that pay is increasing in individual efficiency. More efficient workers provide more effort for which they receive a larger compensation. The stochastic component in (14) depends on the chosen piece rate and individual efficiency. If we let $(1 / 2 c) p_{i}^{2}+p_{i} \varepsilon_{i}=q_{i}$, the wage dispersion within the nonunion firm under performance pay can then be written

$$
\operatorname{Var}(W)=\operatorname{Var}(X)+b^{2} \operatorname{Var}(q)+2 b \operatorname{cov}(X, q) .
$$

First, outside option variation is reflected in the wage structure. Second, efficiency heterogeneity implies that wages differ within firms because workers respond differently to incentives and do not provide the same effort. Finally, when the most efficient workers also have better outside options, the covariance term in (15) is positive and contributes to larger within-firm wage inequality.

Compared to the fixed pay regime, three differences from introducing performance pay stand out. First, wage differentials arise from effort heterogeneity. More efficient workers work harder and they are paid more. Second, wage differentials are reinforced under performance pay due to the positive correlation between efficiency and the outside option. Finally, variability in the unobserved luck component contributes to wage dispersion. The higher the share $(b)$ of productivity that is captured by the worker, the larger is the wage dispersion within the firm. Wage inequality is amplified by high-powered incentives.

\subsection{The Unionized Firm with Collective Bargaining}

The workers bargain collectively (by means of a union) with the firm over parameters of the pay structure and in the case of fixed pay, the effort standard. We consider Pareto optimal outcomes only, which would be the outcome if we assumed Nash bargaining. As long as the relative bargaining power remains the same over different bargaining issues covered by the collective agreement, the outcome is typically efficient. Thus, the outcome may be characterized by maximizing profits for a given level of utility on part of the union, and must satisfy the first order conditions of the Lagrangian $(L)$

$$
L=\sum_{i=1}^{n}\left(\alpha_{i}+\left(1-b_{i}\right) p_{i}\left(z_{i}+\varepsilon_{i}\right)-\omega_{i}-\lambda \bar{z}\right)-\chi \sum_{i=1}^{n}\left(-\exp \left(-a \Psi_{i}\right)-\bar{u}\right)
$$


where $\chi$ is the Lagrange multiplier and $\bar{u}$ defines the average given worker utility level.

\section{Case 3: Union Fixed Pay (UFP)}

Like without unions, fixed pay contracts have $b=0$ and common effort standard. From the first order condition of (16), shown in the Appendix, the optimal effort standard is the same as without union presence, $\bar{z}=(1-\lambda) / c$, unaffected by union power reflected in $(\bar{u})$. The lack of influence of collective bargaining on the optimal common effort follows from the efficient bargaining assumption, in which the parties agree on an effort standard that maximizes the pie (revenue net of effort and monitoring costs). The surplus shares are then determined by negotiations over the fixed component of the pay contract, $\omega_{i}$. The fixed-pay wage structure under collective bargaining is given by:

$$
W_{i}=E(W)=\bar{\Psi}+\frac{1}{2 c}(1-\lambda)^{2}
$$

$$
\operatorname{Var}(W)=0
$$

where $\bar{\Psi}=-\ln (-\bar{u}) / a$. To maximize the collective utility of union members, wages are equated for all workers. The individual participation constraints are now replaced by a union utility constraint. Compared to the nonunion case, the union ensures that potential differences arising from outside option heterogeneity are equalized within the firm. The equalizing effect of the union arises from fact that, with equal effort, a risk-averse union will place more weight on lowpay groups. The most efficient way of satisfying the union utility constraint is thus to provide equal pay. Clearly, this result hinges on the assumption that $\Psi>X_{i} \forall i$, which means that the union is strong enough to ensure that all workers receive a positive rent. ${ }^{7}$

\section{Case 4: Union Individualized Performance Pay (UPP)}

With individualized performance pay, there is no monitoring and individual workers choose effort optimally, $z_{i}=b_{i} p_{i} / c$. Individual worker utility is given by

$$
E U_{i}=-\exp \left(a \Psi_{i}\right), \text { where } \Psi_{i}=\omega_{i}+(1 / 2 c) b_{i}^{2} p_{i}^{2}\left(1-a \sigma^{2} c\right) .
$$

\footnotetext{
${ }^{7}$ Alternatively, one might consider a situation where the binding constraint is the outside options of the highest paid workers, i.e., where low-paid workers rely on coordinated action, while the most productive workers are paid according to their market value. In this case a kinked wage schedule in $X_{\mathrm{i}}$, with wage compression in all but the upper part of the distribution, would result.
} 
The Lagrangian then takes the form

$$
L=\sum_{i=1}^{n}\left(\alpha_{i}+\left(1-b_{i}\right)\left(p_{i}^{2} b_{i} / c\right)-\omega_{i}\right)-\mu \sum_{i=1}^{n}\left(-\exp \left(-a \Psi_{i}\right)-\bar{u}\right)
$$

which is maximized with respect to $b_{i}$ and $\omega_{i}(i=1, \ldots n)$. The first order conditions imply that the optimal piece rate is the same for all workers and equal to that of the nonunion case, see Appendix. Again, the average productivity level is unaffected by the bargaining power of the two parties, just as in the fixed pay regime, because of the efficient bargaining assumption. The wage structure is given by

$$
\begin{aligned}
& W_{i}=\bar{\Psi}+\frac{1}{2 c} b p_{i}^{2}+b p_{i} \varepsilon_{i}==\bar{\Psi}+b q_{i} \\
& \operatorname{Var}(W)=b^{2} \operatorname{Var}(q)
\end{aligned}
$$

The wage has two components that are common to all workers in the firm, determined by the bargaining power of the union and the compensation for risk. More efficient workers provide greater effort and are therefore compensated so as to equalize marginal utility across workers. Finally, the wage captures part of the luck component.

Wage dispersion is lower than in the nonunion case with performance pay, because variation in the outside option does not spill over to wage differentials within the firm. Moreover, since outside options are non-binding, there is no positive association between effort compensation and wage-driving outside factors.

\section{Case 5: Group Performance Pay (GPP)}

As discussed in the introduction, one possible role of the union is to provide a form of selfmonitoring mechanism. We assume that the union is willing to monitor effort only if the standard is the same for all workers, $z_{i}=z$, and provided that the reward system leaves workers with the same expected utility, $\Psi_{i}=\bar{\Psi}$. We justify these assumptions on the grounds that the unions cannot be expected to treat its members differently, particularly when cooperation among workers is required. Since the verification problem facing the employer is the same as before, the effort standard that the union is willing to enforce has to be collectively optimal for its members. In order to induce the union to enforce a higher level of effort, the employer may use a group 
piece rate (denoted $\beta$ to distinguish the notation from the individual piece rate, $b$ ). ${ }^{8}$ With a group bonus, the pay is the sum of a fixed wage and the share of the common effort as well as the average luck; $W_{i}=\omega_{i}+\beta(z+\bar{\varepsilon})$.

(Note that $\frac{1}{n} \sum_{i=1}^{n} p_{i} z=z$ and $\frac{1}{n} \sum_{i=1}^{n} p_{i} \varepsilon_{i}$ is labeled $\bar{\varepsilon}$.)

Expected utility is a function of

$$
\Psi_{i}=\omega_{i}+\beta z-\frac{z^{2}}{2 c}-\frac{1}{2 n} \beta^{2} a c \sigma^{2} .
$$

The optimal effort standard, according to union preferences, is determined by the condition

$$
\frac{\partial \sum-e^{-a \Psi_{i}}}{\partial z}=\sum a e^{-a \Psi_{i}}(\beta-c z)=0
$$

implying that

$$
z=\beta / c \text { when } \Psi_{i}=\bar{\Psi} .
$$

Note that the optimal effort standard is independent of the fixed wage component $\left(\omega_{i}\right)$. This result follows from mechanisms similar to those of the traditional performance pay model and enables the parties to agree on a bonus rate which elicits effort, while the fixed component can be used to smooth utility across workers. The common effort is increasing in the bonus parameter and decreasing in the marginal cost of effort, as with the traditional performance pay schemes.

With a group bonus, the bargaining problem maximizes the Lagrangian

$$
L=\sum_{i=1}^{n}\left(\alpha_{i}+\frac{p_{i} \beta}{c}-\omega_{i}-\frac{p_{i} \beta^{2}}{c}\right)-\mu\left(\frac{1}{n} \sum-\exp \left(-a \Psi_{i}\right)-\bar{u}\right)
$$

and it follows from the first order conditions shown in Appendix that the optimal group bonus rate is

$$
\beta=\frac{1}{1+a c \sigma^{2} / n} .
$$

\footnotetext{
${ }^{8}$ Note that the group bonus could have been an option in the non-union case as well. However, in the absence of union monitoring, the free rider problem implies less effort by each individual with group rates than with individual piece rates.
} 
The group rate is increasing in $n$, providing higher powered incentives in the group bonus case than in the case with individualized performance pay. This result is a reflection of the risk pooling across union members. The wage structure is given by:

$$
\begin{aligned}
& W_{i}=\omega_{i}+\beta(z+\bar{\varepsilon})=E(W)=\bar{\Psi}+\beta\left(\frac{1}{2 c}+\bar{\varepsilon}\right) \\
& \operatorname{Var}(W)=0
\end{aligned}
$$

With a union-bargained group bonus, individual productivity as well as outside option heterogeneity is leveled. The outside options are assumed to be non-binding and all workers supply a common effort standard. Finally, the average luck shock forms the basis for the bonus which is spread equally across workers. In this setting, all workers are paid the same.

\subsection{Summary of Theoretical Predictions}

Wages may differ within firms because of variation in outside options (partly due to observable productivity), heterogeneity in effort efficiency, and luck. Individual performance pay increases the within-firm wage dispersion since individual output luck affects wages. Incentives at the individual worker level also create wage differentials under performance pay because more efficient workers are compensated for higher effort. In a nonunion environment, different outside options will generate wage dispersions across workers in the same firm, even in a fixed pay regime. With performance pay, the effort compensation is positively correlated with outside options, contributing to additional wage variability compared to fixed pay. Thus, when the firm has the power to unilaterally set wages, within-firm dispersion is higher with performance pay.

A union with power to deliver rents to its members contributes to more compressed wages, appearing in our model as an equalization of expected utility across individual workers. With individualized performance pay, union bargaining will also cut the association between efficiency and the outside option as drivers of wages. Thus, our framework unambiguously predicts that the impact of performance pay on wage dispersion is smaller under union bargaining. Finally, wage dispersion within firms with group-based performance pay systems (where an effort standard is monitored by the union) is likely to be similar to that found under fixed-pay collective bargaining. 


\subsection{The Impact of Performance Pay: Empirical Identification}

Our theoretical model clearly suggests that the firm's choice of pay system is endogenous. Firms self-select into pay regimes partly on the basis of worker and firm characteristics which themselves affect within-firm wage dispersion. A comparison of profits across pay systems (see Appendix) easily shows, for example, that the optimal pay system depends on the monitoring technology available to the firm. Furthermore, firms with heterogeneity in worker efficiency will tend to implement individual performance pay. This means that firm-specific heterogeneity can be a predictor of performance pay rather than a result of it. A careful assessment of the impact of performance pay on wage variability thus requires linked employer-employee data. It obviously also requires a strategy for identification, since cross-sectional comparisons of firms or individuals may confound the heterogeneity of firms and workers with the effects of performance pay.

Another complexity is that workers may self-select into firms with different pay schemes. In our model, the firm is able to compensate workers with different efficiencies exactly through the fixed component of the wage. This observation may justify the empirical assumption of random sorting of workers across firms. In practice, however, this may be problematic, as individualized compensation may be less than perfect, inducing self-selection of more efficient workers into firms with performance-based pay systems (see, e.g., the discussion in Lazear, 1995).

In our empirical analyses, we rely on fixed-effects estimators for identification, which allow us to control for time-invariant heterogeneity across firms. Ideally, we would like to model the switching across pay regimes, and use an instrumental variable explaining performance pay without having any direct effect on pay dispersion. Pekkarinen and Riddell (2008) extend the fixed-effects strategy and identify wage effects by tracking workers who changed pay schemes due to establishment closure. In view of our theoretical model, potential instruments would be factors like monitoring technology, idiosyncratic risk, risk aversion, or effort heterogeneity. However, we have not been able to find convincing exclusion restrictions, and thus rely on the fixed-effects methodology. One way to think about the introduction of performance pay schemes, then, is that the switchers represent firms on the margin between pay systems, who happen to change their pay practice during our observational window, for instance as a result of influences such as a change in the management group, labor relations, or even developments in 
the management literature. In contrast, a cross-sectional analysis would look across the total population of firms with and without performance pay schemes, comparing firms with different incentives for their particular pay regime.

\section{Data Sources, Samples, and Variable Construction}

The core of our data material consists of the Norwegian Flexibility Survey 1997 and the 2003 Norwegian Work and Establishment Survey. Both surveys were carried out as computer assisted telephone interviews with either the manager or the chief personnel officer of the establishment. In both surveys, random, but stratified (with respect to establishment size, age, and sector), samples were drawn from the population of Norwegian establishments with more than 10 employees. Questions concerning employees typically related to the "main occupational group" at the establishment. The survey responses were matched with detailed data about the establishment as well as individual records for each of its employees taken from various administrative registers, in particular person-specific files covering gender, education, and age, and matched employer-employee files covering pay, contract period and working hours (in brackets), to form a longitudinal linked employer-employee data set. The administrative records were provided by Statistics Norway and cover all employees in each establishment.

The response rates of the establishment surveys were 76 percent in 1997 and 77 percent in 2003. In the present study, we focus on private sector establishments. In our baseline analyses, we exclude employees working fewer than 30 hours per week, ${ }^{9}$ as well as firms with fewer than ten individual observations in the full-time worker data set (as within-firm differentials are poorly defined in these firms). This leaves us with 2,406 observations of 1,751 establishments with valid data in 1997 or 2003 (covering 137,985 observations in the employee pay data in 1997 and 154,705 observations in 2003). In these samples, 655 establishments are represented in both surveys.

\footnotetext{
${ }^{9}$ In the individual pay records, hours worked are bracketed in three intervals only: 1-19, 20-29, and 30 or more hours per week, which complicates a study of hourly pay. We nevertheless examine whether or not our key results are influenced by sample inclusion of part-time workers in the sensitivity analyses presented in section 4.5.
} 


\subsection{Performance-related Pay}

Both establishment surveys contained questions about performance-related pay. Unfortunately, these questions were not identical in the two surveys. In 1997, respondents were asked whether or not "the main occupational group receives any pay through incentive pay systems, bonuses, or profit sharing?" In 2003, the survey instrument instead included separate questions about six different forms of performance-related pay; (a) Individual and group piece rates, (b) Commissions, (c) Group bonuses, (d) Profit sharing, (e) Individual bonuses, and (f) Merit pay based on individual performance assessments.

Respondents were also asked to estimate the share of total wages that were associated with each type of performance pay. It seems reasonable to assume that managers who in 2003 answered affirmative on the use of at least one the five former pay types (a)-(e) would have answered "yes" to the 1997 question. It is not obvious, however, how establishments with type (f) "merit pay based on individual assessments," would have interpreted the 1997 question. In addition, it is not clear whether the answers refer to permanent or variable elements of compensation. In the empirical analyses, we classify the wage policy at the firm as performancerelated pay in 2003 if the manager answered "yes" on at least one of the types (a)-(f). If "yes" on (f) only, its share of total wages must be at least 3 percent. ${ }^{10}$ Figure 1 displays the incidence of performance pay (and its various components, with piece rates and commissions grouped together) across the wage distribution in 2003. Performance pay schemes at the establishment are prevalent across the wage distribution, although the incidence is rising in the upper half of the distribution-increasing from 60 percent of workers around the median wage to more than 80 percent of workers in the top wage decile (see panel A). As is evident from panels C, E, and F, the higher rate of performance pay in the top of the wage distribution reflects higher incidences of both group and individual based bonuses. In the establishment-level sample covering both survey years, performance-related pay is found in about half of the firms; see Table 1.

Figure 1 around here

Table 1 around here

\footnotetext{
${ }^{10}$ As we show in section 4.5, the core results in this paper are not sensitive to whether we instead use a "strict" definition and only consider items (a)-(e) in the 2003 definition of performance pay.
} 


\subsection{Wage Differentials}

We compute statistics describing the firm-level wage structure from the linked employeremployee records. Our employee-level wage measure is constructed by dividing the total wages paid to the worker through the year by the number of days of the employment relationship. This daily wage rate is then adjusted by means of a regression of individual log wages on educational attainment (seven levels); age and its square; interactions between each education level and the age polynomial; immigrant status; union membership; gender and interactions between gender and all other characteristics; an indicator variable for year of observation; interactions between the year variable and all other regressors as well as establishment-year fixed effects. In the fulltime worker sample, this first-step regression provides 292,690 log wage residuals. From the distribution of individual residuals, we compute the $10^{\text {th }}, 50^{\text {th }}$, and $90^{\text {th }}$ percentiles of the residual $\log$ wage distribution within each establishment for each of the two sample years. Average wages are compared across establishments by means of the set of year-specific fixed effects.

As Table 1 shows, the average 90-10 log wage differential in the sample is .697 and it drops to .607 when we adjust wages for observed characteristics of the workforce. As expected, the wage differentials are larger in firms with performance related pay. The wage differentials in the balanced panel are similar to what is observed in the combined cross sections.

\subsection{Union Density and Control Variables}

Union density is the proportion of workers at the establishment who are members of a union. We collect this information from the manager surveys. If not available in the survey data, we computed the union density from data on individual payments of union membership dues identified through registers and aggregated to the establishment level. Union density reflects the ability of the workers to coordinate industrial actions, see, e.g., Barth et al. (2001), and to promote collective interests with respect to both the level and dispersion of wages. Bargaining structure and the presence of collective agreements are typically correlated with union membership. The sample average union density is close to 60 percent, and membership is lower in firms with performance related pay. Again, the balanced sample appears to be fairly representative.

We include firm size and age as well as industry affiliation (12 major industries) among the firm-level control variables. From the individual data, we calculate the fraction of female 
workers and the skill composition (i.e., the fractions of workers with low and high educational attainment) at the firm level.

Our sample is restricted to the private sector. Due to reorganization of former government monopolies, establishments within postal services and the national telecommunications company (Telenor) were classified as belonging to the public sector in 1997 and to the private sector in 2003.

\section{Empirical Results}

This section reports our empirical estimates of how performance-related pay systems affect wage inequality within firms, but we first look at pay differentials between firms.

\subsection{Performance Pay Raises the Mean Wage, but not by much}

From the theoretical model, we expect firms with performance related pay to have higher wages. The effect arises from the need to compensate workers for the exposure to risk. Note that we do not necessarily expect productivity to be higher with performance-related pay. The reason is that, when firms can monitor worker effort at low costs, they will fix standards at a higher level of effort than the average effort level induced by the performance-pay scheme. Moreover, imperfect differentiation with respect to the outside option creates a sorting incentive (see, e.g., Lazear, 1995), in such a way that more productive workers tend to sort into firms with performance pay. This sorting would induce a positive correlation between performance pay and wages, even though it was not a causal relation. In order to sweep out the effect of such sorting, it is necessary to control carefully for individual characteristics.

Table 2 around here

Table 2 shows a positive effect of performance-pay schemes on the firm average wage level. Workers in firms with performance pay have a pay advantage of 9 percent over workers in firms without performance-related pay, see column (1). The wage premium reflects in part better observed individual characteristics of workers in performance-pay firms; when we account for differences in education, age, and other individual characteristics, the estimated pay advantage drops to 6.6 percent (col. 2). When we also account for differences in observed characteristics of 
firms, such as degree of unionization, firm size, employee composition, and industry, the pay advantage falls even further-to 2.5 percent (col. 3). When we take advantage of the panel dimension of the data and estimate the wage effect of performance-pay schemes including firm fixed effects, the estimate drops even more to 1.8 percent (col. 5). Note that the panel estimates without fixed effects (col. 4) are very similar to those for the full sample, suggesting that the balanced panel is fairly representative.

A possible concern is that these estimates are influenced by selective mobility among workers. For example, high-performing workers may be attracted to firms with performance-pay schemes, in which case the observed pay advantage of performance-pay firms might reflect sorting of workers rather than a true effect of the pay scheme. A simple test is to re-estimate the model for the sub-sample of employees that worked at the same establishment both in 1997 and 2003, see cols. (6) and (7). Results based on the restricted sample reveal slightly larger effects of performance pay than those from the overall sample. Thus, the estimated effect of performance pay is not due to worker sorting across establishments. Of particular interest is the estimated coefficient reported in column (7), which is identified from differential wage growth of employees that experienced the introduction (or elimination) of performance-related pay schemes during the sample period and employees that did not. The estimated effect of performance pay based on this sample is 2.8 percent. ${ }^{11}$ The lower longitudinal estimates of the performance-pay effect may reflect correlation between performance pay and unobserved firm characteristics with positive wage effects, such as superior organization or management. However, any attenuation bias arising from measurement error in the performance-pay variable will be amplified by the fixed effect specification. Our preferred estimate of the firm wage effect is 2.8 percent.

Table 3 around here

\footnotetext{
${ }^{11}$ The restricted sample consists of 79,068 observations of individuals for whom we observe wage payments from the same employer in both survey years. Among these employees, 29.4 percent experienced the introduction and 10.3 percent the elimination of performance pay during the sample period. When we allow for asymmetric impacts of introducing and eliminating performance pay, the estimated coefficient of "Add performance pay" is .029 ( $\mathrm{se}=.012)$ and the coefficient of "Drop performance pay" is -.027 (se=.018).
} 
In Table 3, we examine whether union power and bargaining regime influence the effect of performance pay on firm-level wages. Using union density to summarize the wage setting environment, column (1) suggests that such an interaction does exist. The estimated effect of performance pay in non-unionized firms (i.e., firms with a zero union density) is a 5.4 percent boost in the average wage, while the average wage is largely unaffected by performance pay in fully unionized firms (i.e., 0.6 percent; .054-.048). The empirical evidence on wage differentials between firms in Table 3 is, however, not very strong. When we consider the panel sample, introduce firm fixed effects, or when the sample is restricted to employees at the same workplace both years, the results fail to uncover a significant union interaction on the performance-pay effect on the average firm wage. Overall, Tables 2 and 3 reveal that firms with performancerelated pay have slightly higher wages than those with fixed-pay schemes only.

\subsection{Performance Pay Raises Within-firm Wage Inequality, but less so in Unionized Firms}

Table 4 displays the results from regressions of within-firm wage inequality on firm characteristics, including whether or not the firm has a performance-pay scheme. In column (1) the dependent variable is the $90^{\text {th }}-10^{\text {th }}$ percentile differential in the observed log wage of employees at the establishment, while in columns (2)-(6) the differential is based on the wage residual. As Table 4 shows, wage dispersion is greater in firms with performance pay; the 90-10 differential is $.077 \log$ point higher in performance-pay firms according to the estimate in column (1). Some of that is attributable to variation in worker and firm characteristics. When we account for worker characteristics, the coefficient of the performance-pay indicator drops to .056 (col. 2), and when we add firm characteristics the association between performance pay and within-firm dispersion is reduced to about half of that in observed wages (col. 3). Yet, the association remains statistically significant.

Our theory predicts that performance pay has a modest impact on wage dispersion in firms with union bargaining. When we interact performance pay and union density, the effect seems modest in firms with high union membership although the interaction term is only significant at the 10 percent level (see column 4). In firms without union presence, however, performance pay is associated with considerably higher wage dispersion.

Table 4 around here 
In the balanced panel, we find even stronger empirical support for the effect of performance related pay on within-firm wage inequality (col. 5). In firms without unions (in terms of membership), performance-related pay has a significant and positive effect on wage differentials. In the opposite end with full membership, wage differentials are unaffected by the introduction of performance related pay. One might suspect that these results are driven by unobserved firm characteristics correlated with pay system and organization. However, introducing firm fixed effects in the balanced panel sample has only a negligible impact on coefficient estimates of the performance-pay variables, suggesting that unobserved, timeinvariant heterogeneity is not the driving force behind these empirical patterns.

A second concern is that the effect of performance pay may be nonlinear in union density, and that the interaction term between performance pay and the union share represents a misspecification of the regression model. To check for this possibility, we estimated a more flexible version of the model reported in column (5), replacing the union share variable with categorical variables reflecting ten-percent ranges of union density at the establishment. The key results from the flexible specification are displayed in Figure 2. The figure indicates some nonlinearity of the effect of performance pay on within-firm wage inequality, displaying an inverted-U shape at low levels of unionization and becoming zero for unionization rates above 50 percent. But, as is also evident from the figure, the linear interaction does a fair job of capturing the essence of the relationship_-performance pay increases within-firm wage dispersion at low, but not at high, levels of unionization. ${ }^{12}$ For this reason we proceed with the parsimonious specification of the regression model.

Figure 2 around here

Between 1997 and 2003, the sample average of the dependent variable - the within-firm 90-10 log wage differential conditional on observed worker characteristics—rose by $0.069 \log$ point (not reported in tables). During the same period, there was a 12.6 percentage point increase

\footnotetext{
${ }^{12}$ Twenty-six percent of the sample firms have union shares below 30 percent, and 50 percent have union shares above 70 percent.
} 
in firms' use of performance pay (Barth et al., 2007). ${ }^{13}$ According to the estimates in Table 4, performance pay raises the within-firm $90-10$ differential by $0.041 \log$ points. The implication is that the expansion of performance-based pay systems can explain about 7.5 percent of the observed growth in within-firm wage inequality. ${ }^{14}$ Although performance pay schemes lead to greater within-firm wage dispersion, only a small share of the increase in wage inequality over the sample period can be attributed to more widespread use of performance pay.

\subsection{Performance Pay Affects Wages both at the Top and the Bottom - but only in Nonunion}

\section{Firms}

Further inspections into the impact of performance pay across the wage distribution are provided in Tables 5 and 6. First, Table 5 reveals that the effects are equally strong at the top (90-50) and at the bottom (50-10) of the distribution. Moreover, in unionized firms, introduction of performance-related pay does not seem to affect the wage structure at all, as the coefficient of the interaction term between union density and performance pay takes the opposite sign and is of similar magnitude to the main effect listed in the top row of the table. Cols. (3) and (6) also reveal that time-invariant firm heterogeneity does not explain this pattern as the coefficient estimates of the performance pay variables from the firm-fixed effects models are basically identical to those from models without fixed effects.

Tables 5 and 6 around here

In Table 6, we examine the impact of performance pay at various percentiles of the within-firm residual wage distribution. ${ }^{15}$ Columns (1)-(3) present analyses of determinants of the $90^{\text {th }}$ percentile wage residual within the firm. Results confirm that the impact of performancerelated pay at the top of the wage distribution depends on the degree of unionization within the firm. In nonunion firms the estimated effect is in the range of five to six percent depending on whether or not the regression includes firm fixed effects. Importantly, the effect on top-level

\footnotetext{
${ }^{13}$ This figure agrees with the observed increase in use of bonuses as identified by official wage statistics (Lunde and Grini, 2007).

${ }^{14}$ Based on the average effect in column (3), the calculation is $0.041 *(0.126 / 0.069)=0.075$.

${ }^{15}$ To save space, we only present results based on the balanced panel. Analyses based on the full sample of firms yielded very similar results and are available upon request.
} 
wages declines with the unionization rate of the firm. In firms where all workers are union members, the estimate of the performance-pay effect on the $90^{\text {th }}$ percentile wage is close to zero and statistically insignificant. The cross-sectional estimates suggest a significant and negative main effect of union density, supporting the idea that union power compresses wages at the top of the distribution.

The effects on wages in the lower tail of the within-firm wage distribution are shown in columns (4)-(6). Although estimated with larger standard errors, a striking pattern is that the signs of coefficients from the $10^{\text {th }}$ percentile regressions are opposite those found for the top of the distribution. Indeed, the estimated coefficients suggest that, in nonunion firms, performance pay has a negative effect on the bottom wages in the firm. Results also show a positive interaction with degree of unionization, a result that is statistically significant in the balanced sample even with establishment fixed effects (see column 6). Again, the main effect of higher unionization is to raise the level for the lowest paid, although the evidence is less clear when identified by means of changes in union density (i.e., with fixed effects). As far as the left tail of the within-firm wage distribution is concerned, unions seem to raise the wage of those with lowest pay and also appears to prevent any negative effect that performance-pay schemes may have for these workers.

\subsection{Why Is the Effect of Performance Pay lower in Unionized Firms?}

Our theoretical model predicts that the design of a performance-related pay scheme differs according to union presence. Utilitarian unions have preferences for equality and can assist the firm in monitoring (and sanctioning any lack of) individual effort to sustain group-based incentives. Our data offer a simple distinction between individual (e.g., individual bonuses based on performance) and group-based (e.g., group bonus) performance pay. Unfortunately, this information is not available in the 1997 survey, but the 2003 survey contained detailed questions on various pay components for the major occupational group at the establishment. Here, we define group-based schemes as group bonuses, while other forms of performance pay are classified as individual performance pay. ${ }^{16}$

\footnotetext{
${ }^{16}$ The results are very similar if we include profit sharing as a group-based scheme.
} 
In Table 7, columns (1) and (2), we report results pertaining to firms' introduction of performance-pay schemes over the sample period. Column (1) addresses the probability of having (any kind of) performance pay in 2003 among firms without performance pay six years earlier. Firms with strong unions are less likely to introduce performance pay; the coefficient estimate of union density is significantly negative and shows that, among firms without performance pay in 1997, fully unionized firms were 21 percentage points less likely to adopt a performance pay schedule over the sample period compared to nonunion firms. This observation seems to be at odds with our predictions, since according to the model, bargaining strength should not affect the motive to deviate from fixed pay. Our conjecture is that some of the union opposition is directed against payment schemes that leave greater discretion in the hands of management. In this case, our bargaining model does not apply straightforwardly, as bargaining power is unevenly distributed across the various elements of the contract, and the parties may generally end up with Pareto-inferior outcomes. Performance pay schemes may also be less prevalent in unionized environments simply because union bargaining in itself has qualities similar to a group bonus, through rent sharing that provides incentives for self-monitoring and higher effort.

Among those firms that introduced performance pay, group-based schemes were more likely in the presence of strong unions. In column (2), the coefficient of union density shows that, in the event of an introduction of a performance pay system, fully unionized firms were 24 percentage points more likely to adopt a group-based bonuses compared to firms without union membership.

Table 7 around here

Turning next to within-firm wage dispersion, columns (3) and (4) display the coefficient estimates from equations where the 90-10 residual wage differential is regressed on performance pay and the interaction with group-based systems as well as other firm characteristics. According to the coefficient estimates, individualized performance pay raises within-firm wage inequality by about 7 percent, while a group-based system raises inequality by 3 percent. Importantly, the estimated effect of group-based systems is significantly lower than that of individualized pay. 
Column (5) presents results from estimation of a quasi-fixed effects model, where the within-firm change in wage dispersion between 1997 and 2003 is modeled as a function of the introduction of performance pay, an interaction between introduction and group-based schemes, as well as the change in other time-varying firm characteristics. Firms that introduced individualized performance pay experienced a $0.102 \mathrm{log}$ point increase in wage dispersion. The point estimates suggest a more moderate rise in wage dispersion in firms that introduced a groupbased system, although the interaction effect is significant only at the 10 percent level. Taken together, the evidence in Table 7 shows that the bulk of the effect of performance pay on withinfirm wage dispersion stems from individualized pay systems. Group-based bonuses for the main occupational group have less, if any, impact on wage variability within the firm.

\subsection{Sensitivity Checks}

Our key results show that the introduction of a performance-based pay system will have a small positive effect on the average wage within the establishment and that the effect on wage dispersion will depend on the degree of unionization of the workforce. Moreover, any effect on wage dispersion in limited to individualized pay systems. In this section, we examine whether these results are sensitive to two issues related to sample and variable construction: the inclusion of part-time workers in the first-step samples and exclusion of merit pay from the 2003 variable definition of performance pay. Results are presented in Table 8.

Table 8 around here

Consider first the inclusion of part-time workers. In prior sections, we have focused on the daily wage of full-time workers in order to avoid measurement problems related to unobserved hours worked. However, part-time workers are typically included in empirical studies of pay systems (e.g., Parent, 1999), and it is not inconceivable that performance pay affects labor supply and hours worked. In our data, there is indeed a slight negative correlation between performance pay and the fraction of the workforce on part-time contracts. ${ }^{17}$ The first three columns of Table 8 display results from regressions including part-time workers in the

\footnotetext{
${ }^{17}$ For example, in a regression (not reported in tables) of share of part-time workers on performance pay, the coefficient estimate is -0.037 (s.e. $=0.008)$.
} 
sample. ${ }^{18}$ The table reports estimates drawing on the balanced sample of establishments and within-firm changes in the wage structure and performance pay. Even though performance pay may alter the share of workers in part-time positions, a comparison of the estimates in columns (1)-(3) with previous tables shows that such adjustments only modestly influence our estimates of the effects of performance pay on the within-firm wage structure.

A second data concern is that the performance pay variable may be measured differently in the two sample periods. In particular, it is not clear how firms with merit pay systems responded to the performance pay question asked in 1997. As a sensitivity check, we therefore redefined the variable not counting firms with merit pay only in the performance pay measure in 2003. As the three last columns of Table 8 demonstrate, our findings are not driven by misclassification of performance pay systems--even when we exclude merit pay from the class of performance pay systems, results show significant effects of performance pay on the mean wage of the workforce and on the wage distribution in nonunion firms. Our key empirical findings are thus robust to these two data concerns.

\section{Conclusions}

Theory predicts that wage differentials between and within firms are linked to the choice of pay system. Even if workers are compensated for risk, we do not necessarily find higher productivity in firms with performance-related pay simply because monitoring firms with fixed pay systems are likely to implement higher effort standards than those chosen by workers in performance-pay firms. Wages may vary within firms because of individual differences in outside options, heterogeneity in effort efficiency, and luck. Individual performance pay schemes will enhance the effort and output of the most efficient workers, and, consequently, their pay in order to compensate for effort cost and risk, adding to the variability from luck. As more efficient workers typically have better outside options, the introduction of performance pay also leads to increased wages of workers with high pay in the first place. Thus, when the firm has the power to unilaterally set wages, theory predicts that within-firm wage dispersion is greater with performance pay.

\footnotetext{
${ }^{18}$ When computing establishment wage structure statistics including part-time workers, we first constructed an hourly wage by deflating the weekly wage by 13,23 , and 37.2 hours for the three hours brackets. The log hourly wage then forms the dependent variable of the first-step regression. These hours worked figures correspond to mean hours worked computed from an auxiliary data source (Statistics Norway Wage Statistics).
} 
A union with power to deliver rents to its members contributes to compression of wages, appearing in our model as an equalization of expected utilities across union members. This union wage compression breaks the link between the distribution of outside options and the internal distribution of wages under performance pay. If a firm introduces individual performance pay, the more efficient workers obtain higher pay, but wage inequality is not amplified by the variation in outside options as in the nonunion setting. In addition, group-based performance pay is more likely in a union setting because the union possesses the ability to use collective action to sustain a high effort level and thereby act as a monitoring device for the firm. Unions may thus contribute to solving the asymmetric information problem in order to back their claimed share of productivity gains. Theory, then, suggests that group-based performance pay schemes have minor effects on wage dispersion since effort is more evenly distributed and the risk is pooled across workers.

Empirically, we do find higher wage levels in firms with performance related pay. However, after controlling for individual worker and firm characteristics, the wage premium of performance pay firms drops from 9 to 2 percent. We are not ready to take this as evidence of productivity effects of pay for performance, simply because it may well be compensation for higher risk.

The observed impact of performance pay on within-firm wage dispersion is in line with our theoretical predictions. Individualized performance-related pay schemes raise withinestablishment wage dispersion. The effect of performance pay on wage dispersion is significantly lower in establishments with greater union presence. These results remain after controlling for time-invariant unobserved heterogeneity of establishments.

The impact of performance pay on wage dispersion is significantly lower with groupbased pay schemes than with individualized performance-based pay schemes. Firms that introduce performance pay schemes are more likely to choose group-based pay if there is a strong union present. This evidence is consistent with predictions from our theoretical framework and the notion that the union serves as a self-monitoring device that contributes to solving the free-rider problem associated with group-based pay.

All in all, we conclude that, even though pay for performance is on the rise and does contribute to within-firm wage dispersion, the introduction of performance-based payment 
schemes is unlikely to be a major contributor to increased wage inequality in the highly unionized European labor markets.

\section{References}

Bandiera, Oriana, Iwan Barankay, and Imran Rasul (2005), "Social Preferences and the Response to Incentives: Evidence from Personnel Data," Quarterly Journal of Economics, 120(3), 917-962.

Barth, Erling, Bernt Bratsberg, Torbjørn Hægeland, and Oddbjørn Raaum (2008), "Who Pays for Performance?” International Journal of Manpower, 29(1), 8-29.

Barth, Erling, Robin Naylor, and Oddbjørn Raaum (2001), "Union Wage Effects: Does Membership Matter?” The Manchester School, 68(3), 259-275.

Belfield, Richard, and David Marsden (2003), "Performance Pay, Monitoring Environments, and Establishment Performance," International Journal of Manpower, 24(4), 452-471.

Blanchflower, David G., and Alex Bryson.(2003), "Changes over Time in Union Relative Wage Effects in the UK and the US Revisited," Chapter 7 in International Handbook of Trade Unions, John T. Addison and Claus Schnabel (eds.), Edward Elgar.

Booth, Alison L., and Jeff Frank (1999), "Earnings, Productivity, and Performance-Related Pay," Journal of Labor Economics, 17(3), 447-463.

Booth, Alison L., and Marco Francesconi (2000), "Collectivism versus Individualism: Performance-related Pay and Union Coverage for Non-standard Workers in Britain," ILR working papers 061, Institute for Labour Research.

Brown, Charles (1990), "Firm's Choice of Method of Pay," Industrial and Labor Relations Review, 43(3), 165S-182S.

Brown, Charles (1992), "Wage Levels and Method of Pay," Rand Journal of Economics, 23(3), 366-375.

Brown, Michelle, and John S. Heywood (2002), Paying for Performance: An International Comparison, Armonk NY: M.E. Sharpe.

Cahuc, Pierre, and André Zylberberg (2004), Labor Economics, Cambridge, Mass.: The MIT Press.

Card, David, Thomas Lemieux, and W. Craig Riddell (2004), "Unions and Wage Inequality," Journal of Labor Research, 25(4), 519-562. 
DiNardo, John, Nicole M. Fortin, and Thomas Lemieux (1996), "Labor Market Institutions and the Distribution of Wages 1973-1992, A Semiparametric Approach," Econometrica, 64(5), 1001-1044.

Ewing, Bradley T. (1996), "Wages and Performance-Based Pay: Evidence from the NLSY", Economic Letters, 51(2), 241-246.

Foss, Nicolai J., and Keld Laursen (2005), "Performance Pay, Delegation and Multitasking under Uncertainty and Innovativeness: An Empirical Investigation," Journal of Economic Behavior and Organization, 58(2), 246-276.

Freeman, Richard B., and James Medoff (1984), What Do Unions Do? New York: Basic Books.

Heywood, John, W. Stanley Siebert, and Xiangdong Wei (1997), "Payment by Results Systems: British Evidence," British Journal of Industrial Relations, 35(1), 1-22.

Holmström, Bengt, and Paul Milgrom (1987), "Aggregation and Linearity in the Provision of Intertemporal Incentives," Econometrica, 55(2), 303-328.

Jensen, Michael C., and William H. Meckling (1976), "Theory of the Firm: Managerial Behavior, Agency Costs and Ownership Structure," Journal of Financial Economics, 3(4), 305-360.

Kahn, Lawrence (2000), "Wage Inequality, Collective Bargaining and Relative Employment 1985-94: Evidence from 15 OECD Countries," The Review of Economics and Statistics, 82(4), 564-579.

Kersley, Barbara, Carmen Alpin, John Forth, Alex Bryson, Helen Bewley, Gill Dix, and Sarah Oxenbridge (2006), Inside the Workplace: Findings from the 2004 Workplace Employment Relations Survey, London and New York: Routledge.

Lazear, Edward P. (1986), "Salaries and Piece Rates," Journal of Business, 59(3), 405-431.

Lazear, Edward P. (1995), Personnel Economics, MIT Press.

Lazear, Edward P. (2000), "The Use of Performance Measures in Incentive Contracting," American Economic Review, 90(2), 415-420.

Lazear, Edward P. (2002), "Performance Pay and Productivity," American Economic Review, 90(5), 1346-1361.

Lemieux, Thomas, W. Bentley MacLeod, and Daniel Parent (2009), "Performance Pay and Wage Inequality," Quarterly Journal of Economics, 124(1), 1-49.

Lunde, Harald, and Knut H. Grini (2007), Bonus - hvor mye og til hvem?” Reports 2007/18, Statistics Norway. 
MacLeod, W. Bentley, and Daniel Parent (1999), "Job Characteristics and the Form of Compensation," Research in Labor Economics 18, 177-242.

Metcalf, David (2003), "Unions and Productivity, Financial Performance and Investment: International Evidence," in International Handbook of Trade Unions, John T. Addison and Claus Schnabel (eds.), Edward Elgar, 118-171.

Parent, Daniel (1999), "Methods of Pay and Earnings: A Longitudinal Analysis," Industrial and Labor Relations Review, Vol. 53(1), 71-86.

Pekkarinen, Toumas, and Chris Riddell (2008), "Performance Pay and Earnings: Evidence from Personnel Records," Industrial and Labor Relations Review, 61(3), 297-319.

Pencavel, John (1977), "The Distributional and Efficiency Effects of Trade Unions in Britain," British Journal of Industrial Relations, 15(2), 137-156.

Seiler, Eric (1984), "Piece Rate vs. Time Rate: The Effect of Incentives on Earnings," The Review of Economics and Statistics, 66(3), 363-376.

Shearer, Bruce (2004), "Piece Rates, Fixed Wages and Incentives: Evidence from a Field Experiment," Review of Economic Studies, 71(2), 513-534.

Vroman, Susan B. (1990), "The Union-Nonunion Wage Differential and Monitoring Costs," Economics Letters, 32(4), 405-409. 


\section{Appendix}

Pay determination within the firm is modeled as the outcome of constrained profit maximization, subject to various constraints that differ across pay regimes.

\section{The Nonunion Firm}

In the case of a firm without union representation, the Lagrangian is given by

$$
\begin{aligned}
& L=\sum_{i=1}^{n}\left(\alpha_{i}-\omega_{i}+\left(1-b_{i}\right) p_{i} z_{i}\right)-\lambda n z \\
& -\sum_{i=1}^{n} \mu_{i}\left(\omega_{i}+b_{i} p_{i}\left(z_{i}+\varepsilon_{i}\right)-\frac{c}{2} z_{i}^{2}-\frac{p_{i}^{2} b_{i}^{2}}{2} a \sigma^{2}-X_{i}\right) \\
& -\sum_{i=1}^{n} \xi_{i}\left(z_{i}-\frac{b_{i} p_{i}}{c}\right) \\
& -\sum_{i=1}^{n} \tau_{i}\left(z_{i}-z\right)
\end{aligned}
$$

Here, the outside option constraint is always binding, while only one of the incentive constraints is binding, depending on the pay regime.

Case 1: Fixed Pay (FP); $b_{i}=\xi_{i}=0, \quad z_{i}=z$

Inserting the expression for individual effort, $z_{i}=z$, the first order conditions are

$$
\begin{aligned}
& \frac{\partial L}{\partial \omega_{i}}=-1-\mu_{i}=0 \Rightarrow \mu_{i}=1 \\
& \frac{\partial L}{\partial z}=\sum_{i=1}^{n} p_{i}-\lambda n-\sum_{i=1}^{n} \mu_{i} c z=0 \\
& \Rightarrow \quad z=(1-\lambda) / c \quad \text { as } \frac{1}{n} \sum_{i=1}^{n} p_{i}=1
\end{aligned}
$$

Case 2: Individual Performance Pay (PP); $z=\tau_{i}=0$

Inserting $z_{i}=b_{i} p_{i} / c$, the first order conditions read 


$$
\begin{aligned}
& \frac{\partial L}{\partial \omega_{i}}=-1-\mu_{i}=0 \Rightarrow \mu_{i}=1 \\
& \frac{\partial L}{\partial b_{i}}=\frac{p_{i}^{2}}{c}-2 b_{i} \frac{p_{i}^{2}}{c}+\mu_{i} b_{i} \frac{p_{i}^{2}}{c}+\mu_{i} b_{i} p_{i}^{2} a \sigma^{2}=0 \\
& \Rightarrow \quad b_{i}=\frac{1}{1+a c \sigma^{2}}=b
\end{aligned}
$$

\section{The Union Bargaining Case}

For the unionized firm, the Lagrangian is given by

$$
\begin{aligned}
& L=\sum_{i=1}^{n}\left(\alpha_{i}-\omega_{i}+\left(1-b_{i}\right) p_{i} z_{i}\right)-\lambda n z \\
& -\chi\left(\sum_{i=1}^{n}\left(-e^{-a \psi_{i}}\right)-\bar{u}\right) \\
& -\sum_{i=1}^{n} \xi_{i}\left(z_{i}-\frac{b_{i} p_{i}}{c}\right) \\
& -\sum_{i=1}^{n} \tau_{i}\left(z_{i}-z\right)
\end{aligned}
$$

Relative to the nonunion case, the individual outside option constraints are replaced by the (given) union utility constraint.

Case 3: Union Fixed Pay (UFP); $b_{i}=0, \quad z_{i}=z$

Inserting $z_{i}=z$, the first order conditions are

$$
\begin{aligned}
& \frac{\partial L}{\partial z}=\sum_{i=1}^{n} p_{i}-\lambda n-\chi \sum_{i=1}^{n} a \exp \left(-a \psi_{i}\right) c z=0 \\
& \frac{\partial L}{\partial \omega_{i}}=-1-\chi a \exp \left(-a \psi_{i}\right)=0 \\
& \Rightarrow \quad z=(1-\lambda) / c \quad \text { as } \quad \frac{1}{n} \sum_{i=1}^{n} p_{i}=1
\end{aligned}
$$

Note also that, when $\psi_{i}=\bar{\psi}, \sum_{i=1}^{n}-a \exp \left(-a \psi_{i}\right)=n \bar{u} \Rightarrow \bar{\psi}=-\ln (\bar{u}) / a$.

Case 4: Union Individualized Performance Pay (UPP); $z=0, b_{i}>0$ 
Inserting $z_{i}=b p_{i} / c$, the first order conditions read

$$
\begin{aligned}
& \frac{\partial L}{\partial \omega_{i}}=-1-\chi a \exp \left(-a \psi_{i}\right)=0 \Rightarrow \chi a \exp \left(-a \psi_{i}\right)=-1 \\
& \frac{\partial L}{\partial b_{i}}=\frac{p_{i}^{2}}{c}-2 b_{i} \frac{p_{i}^{2}}{c}+\chi \sum_{i=1}^{n} a \exp \left(-a \psi_{i}\right)\left(\frac{p_{i}^{2}}{c}\left(2 b_{i}-b_{i}\left(1+a c \sigma^{2}\right)\right)=0\right. \\
& \Rightarrow b_{i}=\frac{1}{1+a c \sigma^{2}}=b \\
& \text { and } \bar{\psi}=-\ln (\bar{u}) / a .
\end{aligned}
$$

\section{Case 5: Group Performance Pay (GPP);}

The optimal effort standard is given by $\frac{\partial \sum-e^{-a \Psi_{i}}}{\partial z}=\sum a e^{-a \Psi_{i}}(\beta-c z)=0$ subject to $\Psi_{i}=\bar{\Psi} \Rightarrow z=\beta / c$

Note that in this case the piece rate is labeled $\beta$, instead of $b$. As the Lagrangian reads $L=\sum_{i=1}^{n}\left(\alpha_{i}+(1-\beta) \frac{p_{i} \beta}{c}-\omega_{i}\right)-\vartheta\left(\frac{1}{n} \sum-\exp \left(-a \Psi_{i}\right)-\bar{u}\right)$

and the first order conditions are

$$
\begin{aligned}
& \frac{\partial L}{\partial \omega_{i}}=-1-\chi a \exp \left(-a \psi_{i}\right)=0 \quad \forall i \\
& \frac{\partial L}{\partial \beta}=\sum_{i=1}^{n}\left(\frac{p_{i}}{c}\right)-2 \beta \sum_{i=1}^{n}\left(\frac{p_{i}}{c}\right)-\beta \vartheta \sum_{i=1}^{n} a \exp \left(-a \psi_{i}\right)\left(\frac{2}{c}-\frac{1}{c}\left(1+a c \sigma^{2} / n\right) .\right.
\end{aligned}
$$

When combined, the first order conditions give the expression for the optimal group rate,

$$
\beta=\frac{1}{1+a c \sigma^{2} / n},
$$

since

$$
\frac{1}{n} \sum_{i=1}^{n} p_{i}=1
$$

\section{Profits across Regimes}

In the nonunion (subscript $n u$ ) case, expected profits are equal to 


$$
\pi_{n u}^{P P}=\bar{\alpha}-\bar{X}+\frac{\exp \left(\gamma^{2}\right)}{2 c} \frac{1}{1+a c \sigma^{2}}
$$

and

$$
\pi_{m u}^{F P}=\bar{\alpha}-\bar{X}+\frac{(1-\lambda)^{2}}{2 c}
$$

under performance and fixed pay, respectively. If monitoring costs are sufficiently large, profits are higher with performance pay. In case effort efficiency becomes more dispersed, the average effort is raised (even if the optimal share, $b$, is independent of $\gamma$ ). Thus, with greater worker heterogeneity, performance pay is more likely to be preferred by the firm. Finally, factors that reduce the optimal bonus share $(b)$, such as risk aversion $(a)$ and dispersion of random shocks $\left(\sigma^{2}\right)$, also make performance pay less attractive because average effort and thereby productivity is reduced.

With union presence and efficient bargaining, the ranking of profits is the same (for a given level of union utility), since

$$
\begin{aligned}
& \pi_{u}^{P P}=\bar{\alpha}-\bar{\Psi}+\frac{(1-\lambda)^{2}}{2 c} \\
& \pi_{u}^{P P}=\bar{\alpha}-\bar{\Psi}+\frac{\exp \left(\gamma^{2}\right)}{2 c} \frac{1}{1+a c \sigma^{2}}
\end{aligned}
$$

Even in the presence of unions, individual performance pay is likely to be preferred over fixed pay if monitoring costs are sufficiently large, workers differ in terms of efficiency, risk aversion is low, and if individual productivity is not too heavily influenced by random events.

With a group-based bonus, expected profits are:

$$
\pi_{u}^{G P}=\bar{\alpha}-\bar{\Psi}+\frac{1}{2 c}\left(\frac{1}{1+a c \sigma^{2} / n}\right)
$$

Profits are highest with group-based performance pay if and only if average effort is higher than in the other regimes. Compared to fixed pay, a group-based bonus is likely to be more profitable if monitoring costs are large, risk aversion is low, and if individual productivity is not too heavily influenced by luck. 
Table 1: Firm Characteristics

\begin{tabular}{|c|c|c|c|c|c|c|}
\hline & \multicolumn{3}{|c|}{ Full sample } & \multicolumn{3}{|c|}{ Balanced panel } \\
\hline & $\begin{array}{c}\text { All } \\
\text { firms }\end{array}$ & $\begin{array}{c}\text { Firms } \\
\text { without } \\
\text { perform- } \\
\text { ance pay }\end{array}$ & $\begin{array}{l}\text { Firms with } \\
\text { perform- } \\
\text { ance pay }\end{array}$ & $\begin{array}{l}\text { All } \\
\text { firms }\end{array}$ & $\begin{array}{c}\text { Firms } \\
\text { without } \\
\text { perform- } \\
\text { ance pay }\end{array}$ & $\begin{array}{c}\text { Firms with } \\
\text { perform- } \\
\text { ance pay }\end{array}$ \\
\hline \multicolumn{7}{|l|}{$\begin{array}{l}\text { Within-firm } 90-10 \log \\
\text { wage differential }\end{array}$} \\
\hline Unadjusted & .697 & .655 & .737 & .679 & .628 & .730 \\
\hline Adjusted & .609 & .576 & .639 & .590 & .552 & .629 \\
\hline \multicolumn{7}{|l|}{ Explanatory variables: } \\
\hline Performance pay & .513 & 0 & 1 & .498 & 0 & 1 \\
\hline Share union members & .592 & .670 & .517 & .610 & .683 & .535 \\
\hline $\log ($ Firm size $)$ & 4.492 & 4.498 & 4.486 & 4.522 & 4.556 & 4.488 \\
\hline Firm age/100 & .440 & .476 & .406 & .495 & .531 & .459 \\
\hline Share high education & .221 & .195 & .245 & .211 & .196 & .225 \\
\hline Share low education & .148 & .162 & .135 & .154 & .166 & .142 \\
\hline Share female & .296 & .308 & .285 & .288 & .302 & .275 \\
\hline \multicolumn{7}{|l|}{ Industry: } \\
\hline Oil, mining, energy & .056 & .038 & .072 & .047 & .037 & .057 \\
\hline Nondurables (omitted) & .194 & .229 & .162 & .238 & .275 & .201 \\
\hline Durables & .209 & .230 & .189 & .253 & .263 & .243 \\
\hline Construction & .074 & .046 & .100 & .069 & .039 & .099 \\
\hline Wholesale & .113 & .066 & .158 & .113 & .061 & .166 \\
\hline Retail & .047 & .048 & .046 & .044 & .044 & .045 \\
\hline Transportation & .073 & .108 & .039 & .059 & .090 & .028 \\
\hline Post \& telecom & .015 & .018 & .011 & 0 & 0 & 0 \\
\hline Finance & .036 & .030 & .041 & .029 & .032 & .026 \\
\hline Business services & .111 & .070 & .150 & .080 & .048 & .113 \\
\hline Health & .030 & .051 & .010 & .029 & .051 & .007 \\
\hline Education, pers servic & .038 & .057 & .021 & .038 & .060 & .015 \\
\hline Observations & & 2,406 & & & 1,310 & \\
\hline
\end{tabular}

Note: The adjusted 90-10 differential is based on the residuals from a regression of individual log wages on educational attainment (seven levels); age and its square; interactions between each education level and the age polynomial; immigrant status; union membership; gender and interactions between gender and all other characteristics; an indicator variable for year of observation and interactions between the year variable and all other regressors; and firm-by-year fixed effects. The first-step regression has 292,690 observations. 
Table 2: The Effect of Performance Pay on the Mean Wage

(1)

(2)

(3)

(4)

(5)

(6)

(7)

\begin{tabular}{|c|c|c|c|c|c|c|c|}
\hline $\begin{array}{l}\text { Performance } \\
\text { pay }\end{array}$ & $\begin{array}{c}.090 * * * \\
(.011)\end{array}$ & $\begin{array}{c}.066 * * * \\
(.009)\end{array}$ & $\begin{array}{c}.025 * * * \\
(.007)\end{array}$ & $\begin{array}{l}.022 * * \\
(.009)\end{array}$ & $\begin{array}{l}.018 * * \\
(.008)\end{array}$ & $\begin{array}{c}.035 * * * \\
(.009)\end{array}$ & $\begin{array}{c}.028 * * * \\
(.009)\end{array}$ \\
\hline $\begin{array}{l}\text { Share } \\
\text { union }\end{array}$ & & & $\begin{array}{l}-.010 \\
(.012)\end{array}$ & $\begin{array}{l}-.001 \\
(.014)\end{array}$ & $\begin{array}{l}.040 * \\
(.022)\end{array}$ & $\begin{array}{c}-.029 * * \\
(.014)\end{array}$ & $\begin{array}{l}.016 \\
(.023)\end{array}$ \\
\hline $\begin{array}{l}\log (\text { Firm } \\
\text { size })\end{array}$ & & & $\begin{array}{c}.035 * * * \\
(.003)\end{array}$ & $\begin{array}{c}.034 * * * \\
(.004)\end{array}$ & $\begin{array}{l}-.014 * \\
(.008)\end{array}$ & $\begin{array}{c}.038 * * * \\
(.004)\end{array}$ & $\begin{array}{c}.004 \\
(.009)\end{array}$ \\
\hline $\begin{array}{l}\text { Firm } \\
\text { age/100 }\end{array}$ & & & $\begin{array}{l}.005 \\
(.009)\end{array}$ & $\begin{array}{l}.016 \\
(.011)\end{array}$ & & $\begin{array}{l}-.010 \\
(.011)\end{array}$ & \\
\hline $\begin{array}{l}\text { Share high } \\
\text { educ }\end{array}$ & & & $\begin{array}{c}.364 * * * \\
(.022)\end{array}$ & $\begin{array}{c}.359 * * * \\
(.029)\end{array}$ & $\begin{array}{l}.066 \\
(.076)\end{array}$ & $\begin{array}{l}.303 * * * \\
(.029)\end{array}$ & $\begin{array}{l}.007 \\
(.080)\end{array}$ \\
\hline $\begin{array}{l}\text { Share low } \\
\text { educ }\end{array}$ & & & $\begin{array}{c}-.232 * * * \\
(.038)\end{array}$ & $\begin{array}{c}-.273 * * * \\
(.050)\end{array}$ & $\begin{array}{c}-.175 * * \\
(.073)\end{array}$ & $\begin{array}{c}-.225 * * * \\
(.049)\end{array}$ & $\begin{array}{l}-.127 \\
(.078)\end{array}$ \\
\hline $\begin{array}{l}\text { Share } \\
\text { female }\end{array}$ & & & $\begin{array}{c}-.161 * * * \\
(.020)\end{array}$ & $\begin{array}{c}-.130 * * * \\
(.024)\end{array}$ & $\begin{array}{l}-.087 \\
(.067)\end{array}$ & $\begin{array}{c}-.107 * * * \\
(.024)\end{array}$ & $\begin{array}{l}-.077 \\
(.071)\end{array}$ \\
\hline $\begin{array}{l}\text { Controls: } \\
\text { Individual } \\
\text { charact. }\end{array}$ & No & Yes & Yes & Yes & Yes & Yes & Yes \\
\hline $\begin{array}{l}\text { Firm fixed } \\
\text { effects step } 2\end{array}$ & No & No & No & No & Yes & No & Yes \\
\hline $\begin{array}{l}\text { Observations } \\
\text { Note }\end{array}$ & 2,406 & 2,406 & 2,406 & \multicolumn{2}{|c|}{ Balanced panel } & \multicolumn{2}{|c|}{$\begin{array}{l}\text { Restricted individual } \\
\text { sample }\end{array}$} \\
\hline
\end{tabular}

$* * * / * * / *$ Significant at $1 / 5 / 10$ percent level.

Note: Standard errors are reported in parentheses. The dependent variable in column (1) is the mean establishment $\log$ wage. Dependent variable in columns (2)-(7) is the year-specific establishment fixed effect from the first-step regression described in the note to Table 1 . Second-step regressions are weighted by the observation count of the firm-by-year cell in the first-step regression sample multiplied by the sampling weight for the firm. Inclusion in the second-step regression requires at least ten observations in the firm-by-year cell. The sample in columns (4) and (5) is restricted to the balanced panel of firms. In columns (6) and (7), the firm wage effect is computed from the subsample of individuals working at the same establishment both years. Second-step regressions also control for year of observation and industry (12 major industries). 
Table 3: Union Interaction in the Wage Effect of Performance Pay

(1)

\begin{tabular}{|c|c|c|c|c|c|}
\hline Performance pay & $\begin{array}{c}.054 * * * \\
(.014)\end{array}$ & $\begin{array}{c}.023 \\
(.018)\end{array}$ & $\begin{array}{c}.004 \\
(.017)\end{array}$ & $\begin{array}{l}.044 * * \\
(.018)\end{array}$ & $\begin{array}{l}.033 * \\
(.019)\end{array}$ \\
\hline $\begin{array}{l}\text { Share union } * \\
\text { Performance pay }\end{array}$ & $\begin{array}{c}-.048 * * \\
(.020)\end{array}$ & $\begin{array}{l}-.001 \\
(.025)\end{array}$ & $\begin{array}{l}.021 \\
(.023)\end{array}$ & $\begin{array}{l}-.014 \\
(.025)\end{array}$ & $\begin{array}{l}-.008 \\
(.025)\end{array}$ \\
\hline Share union & $\begin{array}{c}.016 \\
(.016)\end{array}$ & $\begin{array}{c}.001 \\
(.020)\end{array}$ & $\begin{array}{c}.031 \\
(.024)\end{array}$ & $\begin{array}{l}-.021 \\
(.019)\end{array}$ & $\begin{array}{c}.019 \\
(.026)\end{array}$ \\
\hline $\begin{array}{l}\text { Firm fixed effects } \\
\text { Observations } \\
\text { Note }\end{array}$ & $\begin{array}{c}\text { No } \\
2,406\end{array}$ & $\begin{array}{l}\text { No } \\
1,310 \\
\text { Balanc }\end{array}$ & $\begin{array}{c}\text { Yes } \\
1,310 \\
\text { f firms }\end{array}$ & $\begin{array}{c}\text { No } \\
1,385 \\
\text { Restricte }\end{array}$ & $\begin{array}{l}\text { Yes } \\
1,310 \\
1 \text { sample }\end{array}$ \\
\hline
\end{tabular}

Note: Standard errors are reported in parentheses. The dependent variable is the year-specific establishment fixed effect from the first-step individual regression. See also notes to Tables 1 and 2. Regressions control for establishment size and age, shares of high and low education and female workers, year of observation, and major industry. 
Table 4: The Effect of Performance Pay on Within-Firm Log Wage Dispersion

(1)

(2)

(3)

(4)

(5)

(6)

\begin{tabular}{|c|c|c|c|c|c|c|}
\hline Performance pay & $\begin{array}{c}.077 * * * * \\
(.012)\end{array}$ & $\begin{array}{c}.056^{* * * *} \\
(.010)\end{array}$ & $\begin{array}{c}.041 * * * * \\
(.010)\end{array}$ & $\begin{array}{c}.070 * * * \\
(.020)\end{array}$ & $\begin{array}{c}.136^{* * * *} \\
(.026)\end{array}$ & $\begin{array}{c}.104 * * * \\
(.034)\end{array}$ \\
\hline $\begin{array}{l}\text { Share union * } \\
\text { Performance pay }\end{array}$ & & & & $\begin{array}{l}-.047 * \\
(.028)\end{array}$ & $\begin{array}{c}-.131 * * * * \\
(.036)\end{array}$ & $\begin{array}{c}-.134 * * * \\
(.046)\end{array}$ \\
\hline Share union & & & $\begin{array}{l}-.163 * * * \\
(.016)\end{array}$ & $\begin{array}{c}-.137 * * * \\
(.022)\end{array}$ & $\begin{array}{c}-.101 * * * \\
(.029)\end{array}$ & $\begin{array}{l}-.003 \\
(.047)\end{array}$ \\
\hline $\log$ (Firm size) & & & $\begin{array}{c}.015^{* * * *} \\
(.004)\end{array}$ & $\begin{array}{c}.015^{* * * *} \\
(.004)\end{array}$ & $\begin{array}{l}.006 \\
(.006)\end{array}$ & $\begin{array}{l}-.024 \\
(.016)\end{array}$ \\
\hline Firm age/100 & & & $\begin{array}{c}-.059 * * * \\
(.012)\end{array}$ & $\begin{array}{l}-.059 * * * \\
(.012)\end{array}$ & $\begin{array}{c}-.084 * * * * \\
(.016)\end{array}$ & \\
\hline Share high educ & & & $\begin{array}{l}-.048 \\
(.031)\end{array}$ & $\begin{array}{l}-.049 \\
(.031)\end{array}$ & $\begin{array}{l}-.024 \\
(.042)\end{array}$ & $\begin{array}{l}.064 \\
(.149)\end{array}$ \\
\hline Share low educ & & & $\begin{array}{c}.219 * * * \\
(.052)\end{array}$ & $\begin{array}{c}.217 * * * * \\
(.052)\end{array}$ & $\begin{array}{c}.239 * * * \\
(.073)\end{array}$ & $\begin{array}{l}.266^{*} \\
(.145)\end{array}$ \\
\hline Share female & & & $\begin{array}{c}.323 * * * \\
(.027)\end{array}$ & $\begin{array}{c}.319 * * * \\
(.027)\end{array}$ & $\begin{array}{l}.278^{* * * *} \\
(.035)\end{array}$ & $\begin{array}{l}.271 * * \\
(.132)\end{array}$ \\
\hline Year $=2003$ & $\begin{array}{c}.037 * * * * \\
(.012)\end{array}$ & $\begin{array}{c}.048 * * * \\
(.010)\end{array}$ & $\begin{array}{c}.043 * * * \\
(.010)\end{array}$ & $\begin{array}{c}.043 * * * \\
(.010)\end{array}$ & $\begin{array}{c}.050^{* * * *} \\
(.012)\end{array}$ & $\begin{array}{c}.060 * * * \\
(.010)\end{array}$ \\
\hline Constant & $\begin{array}{c}.638^{* * * *} \\
(.010)\end{array}$ & $\begin{array}{c}.555 * * * \\
(.009)\end{array}$ & $\begin{array}{c}.486 * * * * \\
(.028)\end{array}$ & $\begin{array}{c}.471 * * * \\
(.029)\end{array}$ & $\begin{array}{c}.499 * * * \\
(.038)\end{array}$ & \\
\hline $\begin{array}{l}\text { Firm fixed effects } \\
\text { Observations }\end{array}$ & $\begin{array}{c}\text { No } \\
2,406\end{array}$ & $\begin{array}{c}\text { No } \\
2,406\end{array}$ & $\begin{array}{c}\text { No } \\
2,406\end{array}$ & $\begin{array}{c}\text { No } \\
2,406\end{array}$ & $\begin{array}{l}\text { No } \\
1,310 \\
\quad \text { Bala }\end{array}$ & $\begin{array}{c}\text { Yes } \\
1,310 \\
\text { panel }\end{array}$ \\
\hline
\end{tabular}

Note: Standard errors are reported in parentheses. The dependent variable is the within-establishment difference between the $90^{\text {th }}$ and the $10^{\text {th }}$ percentile log wage residual from the step-one regression described in the note to Table 1 , except for in column (1) where the dependent variable is the observed 90-10 log wage differential at the establishment. Regressions in columns (3)-(6) control for 12 major industries. See also notes to Tables 1 and 2. 
Table 5: Performance Pay and Wage Dispersion - Top vs. Bottom

\begin{tabular}{|c|c|c|c|c|c|c|}
\hline & \multicolumn{3}{|c|}{$90-50$} & \multicolumn{3}{|c|}{$50-10$} \\
\hline & (1) & $(2)$ & (3) & (4) & $(5)$ & (6) \\
\hline Performance pay & $\begin{array}{c}.040 * * * \\
(.010)\end{array}$ & $\begin{array}{c}.060 * * * \\
(.013)\end{array}$ & $\begin{array}{c}.048 * * * \\
(.016)\end{array}$ & $\begin{array}{l}.030^{*} \\
(.016)\end{array}$ & $\begin{array}{l}.075 * * * \\
(.020)\end{array}$ & $\begin{array}{l}.056 * * \\
(.028)\end{array}$ \\
\hline $\begin{array}{l}\text { Share union } * \\
\text { Performance pay }\end{array}$ & $\begin{array}{c}-.038 * * * \\
(.0134\end{array}$ & $\begin{array}{c}-.054 * * * \\
(.018)\end{array}$ & $\begin{array}{c}-.057 * * * \\
(.021)\end{array}$ & $\begin{array}{l}-.009 \\
(.022)\end{array}$ & $\begin{array}{c}-.077 * * * \\
(.028)\end{array}$ & $\begin{array}{c}-.077 * * \\
(.037)\end{array}$ \\
\hline Share union & $\begin{array}{c}-.075 * * * \\
(.010)\end{array}$ & $\begin{array}{c}-.071 * * * \\
(.014)\end{array}$ & $\begin{array}{l}.027 \\
(.022)\end{array}$ & $\begin{array}{c}-.062 * * * \\
(.018)\end{array}$ & $\begin{array}{l}-.031 \\
(.022)\end{array}$ & $\begin{array}{l}-.030 \\
(.039)\end{array}$ \\
\hline $\log ($ Firm size $)$ & $\begin{array}{c}.013 * * * \\
(.002)\end{array}$ & $\begin{array}{c}.007 * * * \\
(.003)\end{array}$ & $\begin{array}{l}-.011 \\
(.007)\end{array}$ & $\begin{array}{c}.002 \\
(.003)\end{array}$ & $\begin{array}{l}-.001 \\
(.004)\end{array}$ & $\begin{array}{l}-.013 \\
(.013)\end{array}$ \\
\hline Firm age/100 & $\begin{array}{c}-.012 * * \\
(.006)\end{array}$ & $\begin{array}{c}-.017 * * \\
(.008)\end{array}$ & & $\begin{array}{c}-.047 * * * \\
(.010)\end{array}$ & $\begin{array}{c}-.067 * * * \\
(.013)\end{array}$ & \\
\hline Share high educ & $\begin{array}{c}.092 * * * \\
(.015)\end{array}$ & $\begin{array}{c}.081 * * * \\
(.021)\end{array}$ & $\begin{array}{l}.028 \\
(.069)\end{array}$ & $\begin{array}{c}-.141 * * * \\
(.025)\end{array}$ & $\begin{array}{c}-.105 * * * \\
(.033)\end{array}$ & $\begin{array}{l}.037 \\
(.122)\end{array}$ \\
\hline Share low educ & $\begin{array}{l}.095 * * * \\
(.025)\end{array}$ & $\begin{array}{c}.141 * * * \\
(.036)\end{array}$ & $\begin{array}{l}.089 \\
(.067)\end{array}$ & $\begin{array}{l}.129 * * * \\
(.040)\end{array}$ & $\begin{array}{l}.099 * \\
(.057)\end{array}$ & $\begin{array}{l}.177 \\
(.118)\end{array}$ \\
\hline Share female & $\begin{array}{c}.065 * * * \\
(.013)\end{array}$ & $\begin{array}{c}.053^{* * * *} \\
(.017)\end{array}$ & $\begin{array}{l}.009 \\
(.061)\end{array}$ & $\begin{array}{l}.255 * * * \\
(.022)\end{array}$ & $\begin{array}{l}.225 * * * \\
(.027)\end{array}$ & $\begin{array}{l}.261 * * \\
(.107)\end{array}$ \\
\hline Year $=2003$ & $\begin{array}{l}.011 * * \\
(.005)\end{array}$ & $\begin{array}{c}.021 * * * \\
(.006)\end{array}$ & $\begin{array}{l}.023 * * * \\
(.005)\end{array}$ & $\begin{array}{l}.032 * * * \\
(.008)\end{array}$ & $\begin{array}{l}.029 * * * \\
(.010)\end{array}$ & $\begin{array}{c}.037 * * * \\
(.008)\end{array}$ \\
\hline Constant & $\begin{array}{l}.215 * * * \\
(.014)\end{array}$ & $\begin{array}{l}.229 * * * \\
(.019)\end{array}$ & & $\begin{array}{l}.256 * * * \\
(.023)\end{array}$ & $\begin{array}{l}.270 * * * \\
(.030)\end{array}$ & \\
\hline $\begin{array}{l}\text { Firm fixed effects } \\
\text { Observations }\end{array}$ & $\begin{array}{c}\text { No } \\
2,406\end{array}$ & $\begin{array}{l}\text { No } \\
1,310 \\
\text { Bala }\end{array}$ & $\begin{array}{c}\text { Yes } \\
1,310 \\
\text { panel }\end{array}$ & $\begin{array}{c}\text { No } \\
2,406\end{array}$ & $\begin{array}{l}\text { No } \\
1,310 \\
\text { Balan }\end{array}$ & $\begin{array}{l}\text { Yes } \\
1,310 \\
\text { anel }\end{array}$ \\
\hline
\end{tabular}

Note: Standard errors are reported in parentheses. The dependent variable in columns (1) - (3) is the withinestablishment difference between the $90^{\text {th }}$ and the $50^{\text {th }}$ percentile log wage residual from the step one regression described in note to Table 1. Columns (4)-(6) display results for the 50-10 log wage differential. Regressions control for 12 major industries. See also notes to Tables 1 and 2. 
Table 6: Performance Pay and the Within-Firm $90^{\text {th }}$ and $10^{\text {th }}$ Percentile Wage

\begin{tabular}{|c|c|c|c|c|c|c|}
\hline & (1) & $\begin{array}{l}0^{\text {th }} \text { Percentile } \\
\text { (2) }\end{array}$ & (3) & (4) & $\begin{array}{l}0^{\text {th }} \text { Percenti } \\
\text { (5) }\end{array}$ & (6) \\
\hline Performance pay & $\begin{array}{c}.039 * * * \\
(.009)\end{array}$ & $\begin{array}{c}.060 * * * \\
(.012)\end{array}$ & $\begin{array}{c}.052 * * * \\
(.015)\end{array}$ & $\begin{array}{c}-.031 * * \\
(.013)\end{array}$ & $\begin{array}{c}-.075 * * * \\
(.017)\end{array}$ & $\begin{array}{c}-.052 * * \\
(.023)\end{array}$ \\
\hline $\begin{array}{l}\text { Share union } * \\
\text { Performance pay }\end{array}$ & $\begin{array}{c}-.031 * * \\
(.013)\end{array}$ & $\begin{array}{c}-.053 * * * \\
(.016)\end{array}$ & $\begin{array}{c}-.064 * * * \\
(.020)\end{array}$ & $\begin{array}{l}.016 \\
(.018)\end{array}$ & $\begin{array}{c}.077 * * * \\
(.024)\end{array}$ & $\begin{array}{l}.070 * * \\
(.031)\end{array}$ \\
\hline Share union & $\begin{array}{c}-.071 * * * \\
(.010)\end{array}$ & $\begin{array}{c}-.063 * * * \\
(.013)\end{array}$ & $\begin{array}{l}.007 \\
(.020)\end{array}$ & $\begin{array}{c}.066 * * * \\
(.015)\end{array}$ & $\begin{array}{l}.039 * * \\
(.019)\end{array}$ & $\begin{array}{l}.011 \\
(.032)\end{array}$ \\
\hline $\log ($ Firm size $)$ & $\begin{array}{l}.012 * * * \\
(.002)\end{array}$ & $\begin{array}{l}.006 * * \\
(.002)\end{array}$ & $\begin{array}{l}-.011 \\
(.007)\end{array}$ & $\begin{array}{l}-.003 \\
(.003)\end{array}$ & $\begin{array}{l}.000 \\
(.004)\end{array}$ & $\begin{array}{l}.013 \\
(.011)\end{array}$ \\
\hline Firm age/100 & $\begin{array}{c}-.021 * * * \\
(.005)\end{array}$ & $\begin{array}{c}-.028 * * * \\
(.007)\end{array}$ & & $\begin{array}{c}.038 * * * \\
(.008)\end{array}$ & $\begin{array}{c}.056 * * * \\
(.010)\end{array}$ & \\
\hline Share high educ & $\begin{array}{l}.026^{* *} \\
(.014)\end{array}$ & $\begin{array}{l}.021 \\
(.019)\end{array}$ & $\begin{array}{l}-.013 \\
(.064)\end{array}$ & $\begin{array}{c}.075 * * * \\
(.020)\end{array}$ & $\begin{array}{l}.045^{*} \\
(.028)\end{array}$ & $\begin{array}{l}-.077 \\
(.102)\end{array}$ \\
\hline Share low educ & $\begin{array}{c}.107 * * * \\
(.023)\end{array}$ & $\begin{array}{c}.134 * * * \\
(.033)\end{array}$ & $\begin{array}{l}.107 * \\
(.062)\end{array}$ & $\begin{array}{c}-.110 * * * \\
(.034)\end{array}$ & $\begin{array}{c}-.105 * * \\
(.047)\end{array}$ & $\begin{array}{l}-.159 \\
(.099)\end{array}$ \\
\hline Share female & $\begin{array}{c}.115^{* * * *} \\
(.012)\end{array}$ & $\begin{array}{c}.100 * * * \\
(.016)\end{array}$ & $\begin{array}{l}.055 \\
(.056)\end{array}$ & $\begin{array}{c}-.110 * * * \\
(.034)\end{array}$ & $\begin{array}{c}-.118 * * * \\
\quad(.023)\end{array}$ & $\begin{array}{c}-.215^{* *} \\
(.090)\end{array}$ \\
\hline $\begin{array}{l}\text { Firm fixed effects } \\
\text { Observations }\end{array}$ & $\begin{array}{c}\text { No } \\
2,406\end{array}$ & $\begin{array}{l}\text { No } \\
1,310 \\
\text { Balanc }\end{array}$ & $\begin{array}{l}\text { Yes } \\
1,310 \\
\text { panel }\end{array}$ & $\begin{array}{c}\text { No } \\
2,406\end{array}$ & $\begin{array}{c}\text { No } \\
1,310 \\
\text { Balan }\end{array}$ & $\begin{array}{c}\text { Yes } \\
1,310 \\
\text { anel }\end{array}$ \\
\hline
\end{tabular}

Note: Standard errors are reported in parentheses. The dependent variable is the within-establishment $90^{\text {th }}$ or $10^{\text {th }}$ percentile log wage residual from the step one regression described in note to Table 1. Regressions control for year of observation and major industry. See also notes to Tables 1 and 2. 
Table 7: Individual and Group-Based Performance Pay

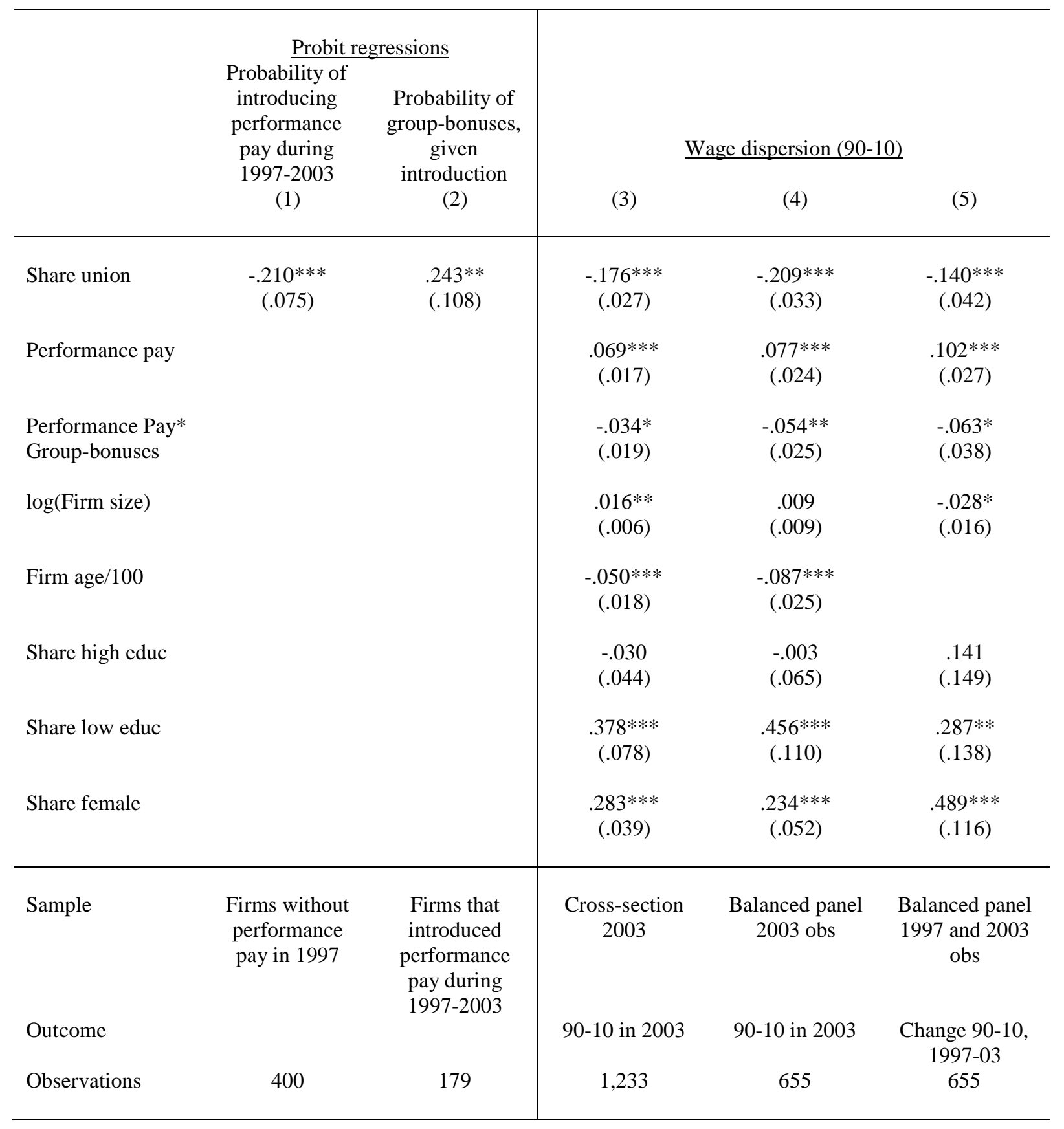

Note: Standard errors are reported in parentheses. Estimates in columns (1)-(2) are based on probit models; reported are marginal effects $(\mathrm{dP} / \mathrm{dX})$. In columns (3)-(4), the dependent variable is the within-establishment 90-10 log wage differential in 2003, and in column (5) the change in the 90-10 differential from 1997 to 2003. In column (5),

regressors are differenced between their 2003 and 1997 values. Regressions are weighted by the observation count of the firm-by-year cell in the first-step regression sample multiplied by the sampling weight for the firm.

Regressions in cols. (3)-(4) control for major industry. 
Table 8: Sensitivity Analyses

\begin{tabular}{|c|c|c|c|c|c|c|}
\hline & $\begin{array}{c}\text { Mean wage } \\
\text { (1) }\end{array}$ & $\begin{array}{c}90-10 \\
\text { differential } \\
\text { (2) }\end{array}$ & $\begin{array}{c}\text { Change in } \\
90-10 \text { diff, } \\
1997-2003 \\
\text { (3) }\end{array}$ & $\begin{array}{l}\text { Mean wage } \\
\text { (4) }\end{array}$ & $\begin{array}{c}90-10 \\
\text { differential } \\
(5)\end{array}$ & $\begin{array}{c}\text { Change in } \\
90-10 \text { diff, } \\
1997-2003 \\
\text { (6) }\end{array}$ \\
\hline Performance pay & $\begin{array}{c}.027 * * * \\
(.009)\end{array}$ & $\begin{array}{l}.094 * * \\
(.041)\end{array}$ & & $\begin{array}{l}.026 * * * \\
(.009)\end{array}$ & $\begin{array}{l}.067 * * \\
(.026)\end{array}$ & \\
\hline $\begin{array}{l}\text { Share union } * \\
\text { Performance pay }\end{array}$ & & $\begin{array}{l}-.120 * * \\
(.055)\end{array}$ & & & $\begin{array}{c}-.081 * * \\
(.035)\end{array}$ & \\
\hline Share union & $\begin{array}{l}-.004 \\
(.024)\end{array}$ & $\begin{array}{l}-.019 \\
(.057)\end{array}$ & $\begin{array}{c}-.170 * * * \\
(.050)\end{array}$ & $\begin{array}{l}.016 \\
(.023)\end{array}$ & $\begin{array}{l}-.025 \\
(.046)\end{array}$ & $\begin{array}{c}-.137 * * * \\
(.042)\end{array}$ \\
\hline $\begin{array}{l}\text { Add performance } \\
\text { pay }(\mathrm{PP})\end{array}$ & & & $\begin{array}{l}.092 * * * \\
(.032)\end{array}$ & & & $\begin{array}{l}.136 * * * \\
(.031)\end{array}$ \\
\hline $\begin{array}{l}\text { Add PP*group } \\
\text { bonus }\end{array}$ & & & $\begin{array}{l}-.076^{*} \\
(.045)\end{array}$ & & & $\begin{array}{c}-.097 * * \\
(.041)\end{array}$ \\
\hline Comment & \multicolumn{3}{|c|}{ Include part time workers } & \multicolumn{3}{|c|}{ Drop merit pay from 2003 definition } \\
\hline Table reference & $2(7)$ & $4(6)$ & $7(5)$ & $2(7)$ & $4(6)$ & $7(5)$ \\
\hline $\begin{array}{l}\text { Firm fixed effects } \\
\text { Observations }\end{array}$ & $\begin{array}{l}\text { Yes } \\
1,310\end{array}$ & $\begin{array}{c}\text { Yes } \\
1,310\end{array}$ & $\begin{array}{l}\text { No } \\
655\end{array}$ & $\begin{array}{c}\text { Yes } \\
1,310\end{array}$ & $\begin{array}{l}\text { Yes } \\
1,310\end{array}$ & $\begin{array}{l}\text { No } \\
655\end{array}$ \\
\hline
\end{tabular}

Note: Standard errors are reported in parentheses. The dependent variable in cols. (1) and (4) is the year-specific establishment fixed effect described in Table 2; in cols. (2) and (5) the within-establishment difference between the $90^{\text {th }}$ and the $10^{\text {th }}$ percentile log wage residual described in Table 4; and in cols. (3) and (6) the within-establishment change in the 90-10 differential between 1997 and 2003. 
Figure 1: Incidence of Performance Pay across the Wage Distribution

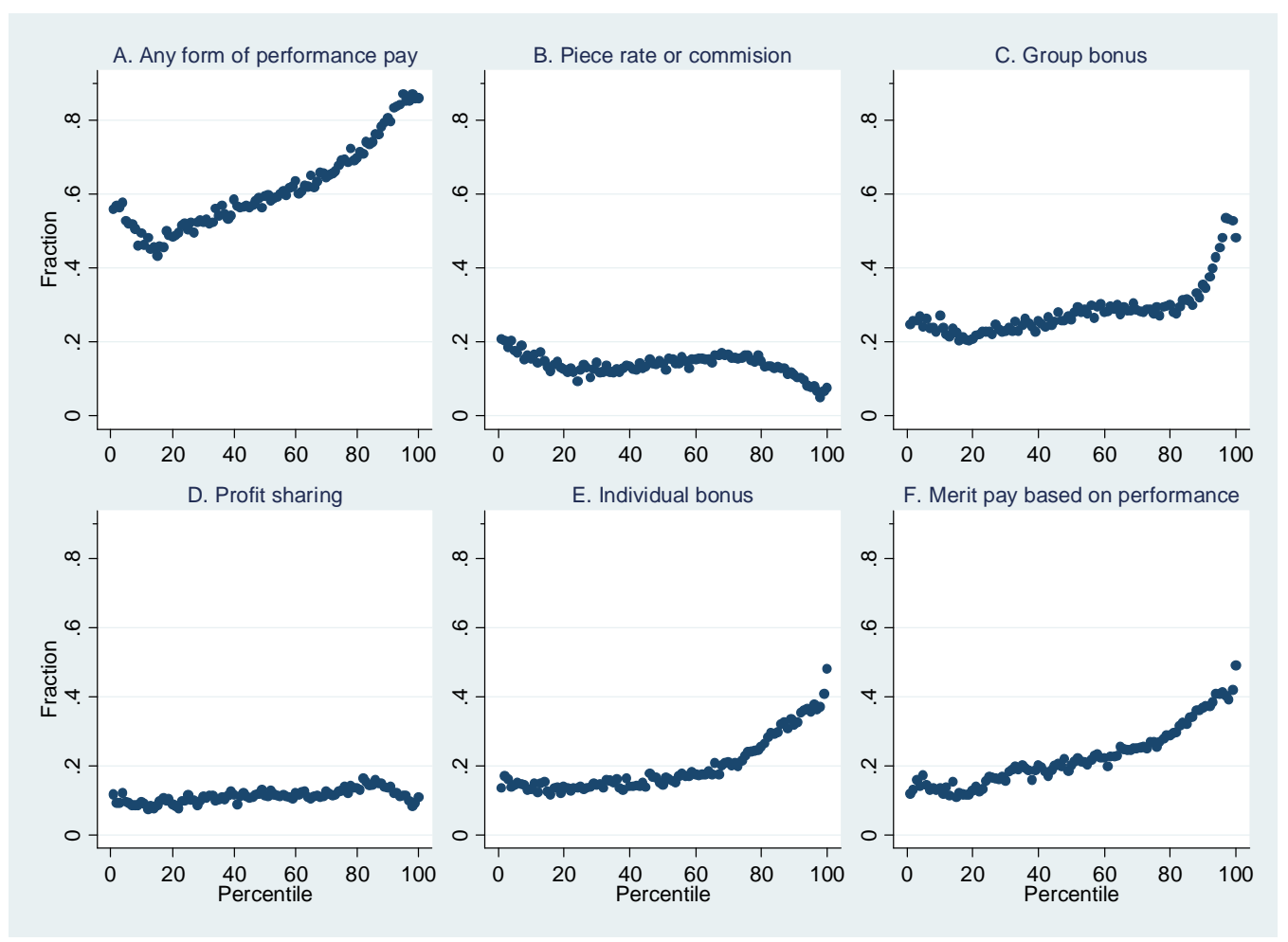

Note: Figure shows fraction of workers at each percentile of 2003 wage distribution with performance pay (panel A) and each of five forms of performance pay (panels B-F) at their establishment. 
Figure 2: Effect of Performance Pay on Within-firm Wage Inequality by Union Density

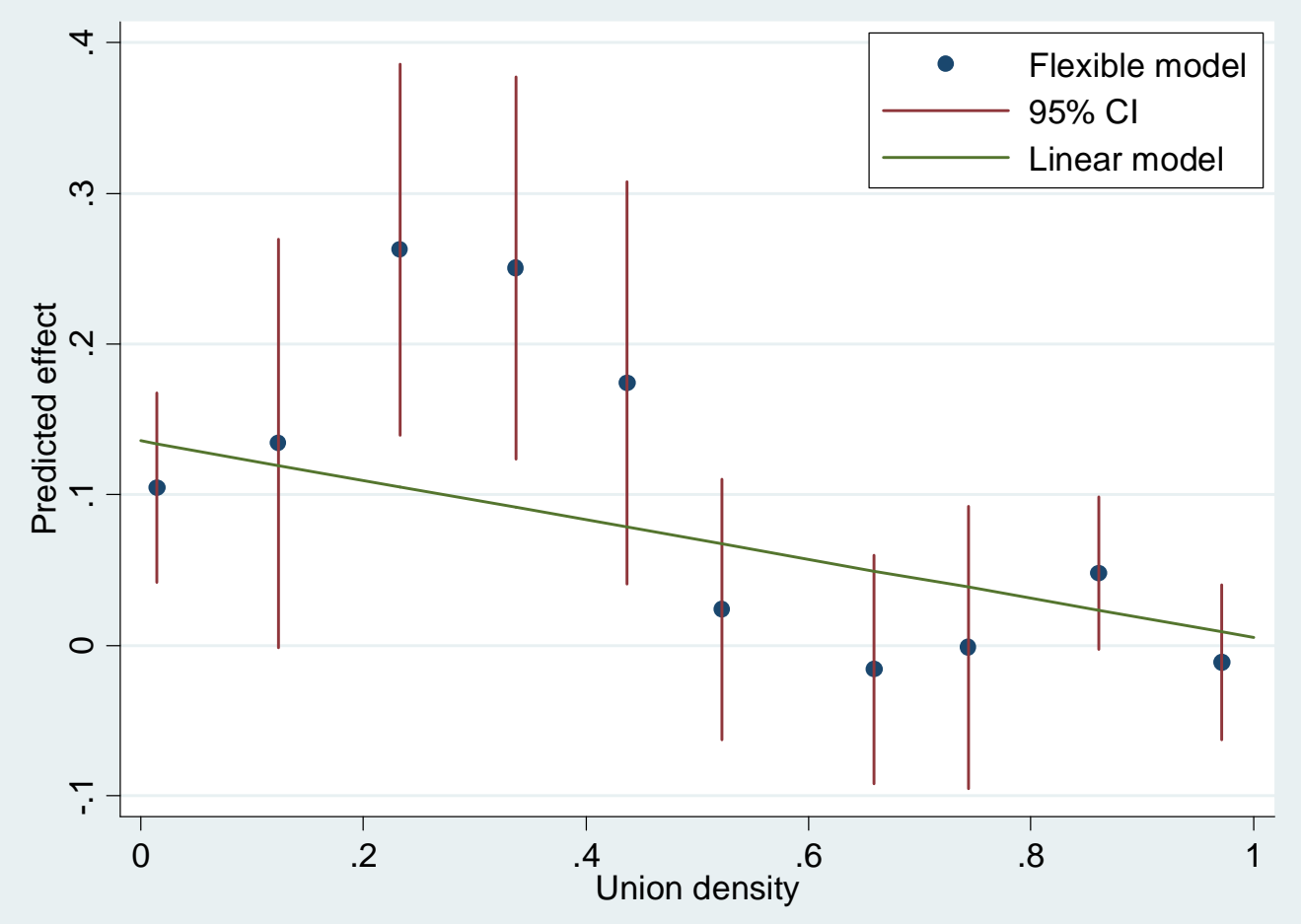

Note: Linear predictions are based on results reported in Table 4, column (5). The flexible model adopts the same regression specification, but with ten indicator variables (each representing a 10 percent range) replacing union density. Scatter points are displayed relative to within-range sample mean union density. 